\title{
LA ICONOGRAFÍA DE CRISTO OCULTO Y LA «FE OSCURA» DE S. JUAN DE LA CRUZ
}

\author{
HIDDEN CHRIST'S ICONOGRAPHY \\ AND S. JUAN DE LA CRUZ'S “DARK FAITH”
}

\author{
MARÍA José CUESTA GARCíA DE LEONARDO \\ Universidad de Castilla-La Mancha \\ https://orcid.org/0000-0001-5294-1935
}

Recibido: 23/06/2020 Evaluado: 01/12/2020 Aprobado: 13/12/2020

RESUMEN: Al poco de morir Juan de la Cruz, en los inicios del siglo XVII, se intenta su canonización. Para ello se buscan imágenes que aludan al mismo, con carácter milagroso y haciendo referencia a su doctrina. Remitiéndonos a distintos textos, veremos cómo sus seguidores construyen una imagen inédita para materializar un concepto, el de la «Fe oscura», usando el término dado por el creador de este, Juan de la Cruz.

Palabras clave: S. Juan de la Cruz, Cristo oculto, Fe oscura, C. Boel, K. Knyf, C. de Mallery, Carmelitas descalzos, Siglos XVI-XVII.

ABSTRACT: Shortly after the death of Juan de la Cruz, at the beginning of the 17th century, his canonization was attempted. For this purpose, images that allude to it are sought. The images that were tried to find had a miraculous character and made reference to its doctrine. Referring to different texts, we will see how his followers build an unknown image to materialize a concept, that of the "Dark faith", using the term given by its author, Juan de la Cruz. 
Key words: S. Juan de la Cruz, Hidden Christ, Dark Faith, Discalced Carmelites, XVI-XVII Centuries.

Mi estudio, de un momento posterior a la muerte de Juan de la Cruz, versa sobre dos aspectos paralelos: uno testimonia la valoración de la imagen como trasmisora de sentimientos, creencias, formas de comprender el mundo y de comportamiento. En este sentido J. A. Maravall ${ }^{1}$ señala: «Utilizando los medios plásticos, la cultura del siglo XVII puede llevar a cabo, con la mayor adecuación, sus fines de propaganda [...] La imagen es un recurso eficaz»; por eso, «no se intenta conceptualizar la imagen, sino dar el concepto hecho imagen». Y este es el segundo aspecto: ver cómo se construye una imagen para materializar un concepto, el de la «Fe oscura», usando el término dado por su creador, Juan de la Cruz.

Empecemos por la historia: Juan de Yepes Álvarez, Juan de la Cruz, nace en Fontiveros (Ávila), el 24 de junio de 1542. Su familia, muy humilde, se traslada a Medina del Campo; aquí estudia con los jesuitas e ingresa en los carmelitas. Tuvo protagonismo en la reforma descalza, lo que le enfrentó a los Calzados; punto culminante fue su encarcelamiento por estos, en Toledo. Fallece en Úbeda el 14 de diciembre de $1591 .^{2}$ Su proceso de beatificacióncanonización (1675 y 1726), a diferencia de la rapidez del de Sta. Teresa, fue largo y complejo; en el contexto de este intento es donde integramos la historia de una reliquia de su cuerpo.

Juan tuvo un hermano mayor, Francisco. Los historiadores de la época lo presentan como venerable varón; los actuales lo ven ignorante, manipulable y pícaro: tras una vida de miseria, habría buscado su beneficio en una reliquia ${ }^{3}$ de Juan, que le posibilitó morir con desahogo económico y reconocimiento. ${ }^{4}$

Muerto Juan, se suceden los cortes de su cuerpo para reliquias. Máxime cuando, en la disputa entre Úbeda y Segovia por sus restos, en 1606, el general de la Orden, Francisco de la Madre de Dios, ordena al P. Alonso de la

1. José Antonio Maravall: La cultura del Barroco, Madrid: Ariel, 1980, p. 501.

2. Para la vida de Juan de la Cruz, ver: Crisógono de Jesús Sacramentado: Vida de San Juan de la Cruz, Madrid: B.A.C., 1946. Eulogio de la Virgen del Carmen: «Primeras ediciones del Cántico Espiritual», en Ephemerides Carmeliticae, 18, 1, 1967, pp. 3-48. EFrÉN DE LA MADRE DE Dios y O. STEGGING: Tiempo y vida de S. Juan de la Cruz, Madrid: B.A.C., 1992. Emilio J. MARTínez GonzÁlez: Tras las huellas de Juan de la Cruz. Nueva biografía, Madrid: Ed. Espiritualidad, 2006.

3. Sobre el uso de las reliquias en época postridentina: José Luis BouzÁ Álvarez, Antonio Domínguez Ortiz y Julio Caro Baroja: Religiosidad contrarreformista y cultura simbólica del Barroco, Madrid: CSIC, 1990, pp. 23-46. Y para el caso que nos ocupa: TeófANEs EgIDO: «Claves históricas para la comprensión de San Juan de la Cruz», en SAlvador Ros et al.: Introducción a la lectura de San Juan de la Cruz, Salamanca, Junta de Castilla y León, Consejería de Cultura y Turismo, 1991, pp. 59-124.

4. Pablo M. Garrido: S. Juan de la Cruz y Francisco de Yepes. En torno a la biografía de los dos hermanos, Salamanca: Sígueme, 1989. 
Madre de Dios (Martínez, el Asturicense) que le trocee y mande partes de Segovia a Úbeda. Egido señala: «La comunidad, con priores entusiasmados como el P. Alonso de la Madre de Dios [...] había tomado ya conciencia del valor atesorado que el pueblo veneraba con tanto fervor»: el cuerpo de Juan; y explica cómo las reliquias asociadas a milagros responden a la precariedad de la época y son «instrumento de propaganda no solo del santo en cuestión sino también de la orden religiosa a la que perteneciera»: ${ }^{5}$ todo sirve para promocionar la beatificación cuya causa inicia otro general, José de Jesús María (Martínez Medina), en $1613 .^{6}$

La historia dice que Francisco, añorando al hermano muerto y ya que tenía un trato cercano con Cristo, le pide volver a verlo. Cristo se lo concede y, desde la Epifanía de 1594, ${ }^{7}$ lo contempla en el trozo de carne que poseía, del «tamaño de un real de a dos». ${ }^{8}$ Lo ve arrodillado, con su hábito del Carmelo Descalzo, ante la Virgen, con el mismo hábito y el Niño en brazos. Esta visión la completa luego con la de un crucificado y la mantiene hasta su muerte en 1607. Hasta aquí el testimonio de Francisco, recogido en la causa que estudiará el carácter milagroso de la reliquia (Mss- 012738-012, pp. 587-592, B.N.). En tal causa -integrada en los informes para la canonización de Juan-, comenzamos a ver el protagonismo de tres carmelitas: el mencionado José de Jesús María (Martínez Medina), el homónimo José de Jesús María (Quiroga), primer historiador del Carmen Descalzo (desde 1597), y el también citado Alonso de la Madre de Dios (Martínez, el Asturicense), procurador de la causa de beatificación; los dos últimos son biógrafos de Juan.

Al testimonio de Francisco se añaden los de carmelitas cercanos al él, que amplían su visión originaria -aunque siempre remitiéndose a los supuestos relatos de este. Y a lo descrito, se añade la imagen de Francisco quien, poco antes de morir, se habría visto a sí mismo en la escena de su visión. Su biógrafo, Velasco, ${ }^{9}$ añade la explicación que el propio Cristo da a Francisco,

5. TeÓfanes EgIdo: «Claves históricas para la comprensión de San Juan de la Cruz», en SAlvador Ros et al.: Introducción a la lectura de San Juan de la Cruz, Salamanca, Junta de Castilla y León, Consejería de Cultura y Turismo, 1991, pp. 115-117.

6. Fortunato Antolín: José de Jesús María (Quiroga), Alonso de la Madre de Dios, Jerónimo de S. José (Ezquerra). Primeras biografías y apologías de S. Juan de la Cruz, Salamanca: Junta de Castilla y León, Consejería de Cultura y Turismo, 1991, pp. 15-18.

7. Sobre el ambiente exaltado en torno a la reliquia milagrosa recordemos que, desde marzo de 1588 y a lo largo de los años 90, se producen en Granada (donde el mismo S. Juan ha vivido de 1582 a 1588 como Prior de su convento) los falsos descubrimientos de las reliquias de los mártires del Sacromonte, S. Cecilio y sus discípulos, apóstoles del cristianismo en la zona. Y el granadino carmelita descalzo e historiador de la orden, Francisco de Santa María, comenta, devoto y admirado, tales encuentros, en el contexto de la vida de Juan de la Cruz. FranCisCo dE SANTA MARÍA: Reforma de los Descalzos de Nuestra Señora del Carmen, Madrid: Diego Díaz de la Carrera, 1655, pp. 334-335

8. José de Jesús María (Martínez Medina) y Vigil de Quiñones: Relación de un insigne milagro que Nuestro Señor obra continuamente en una parte de carne del Venerable Padre Fray Juan de la Cruz, Madrid: Viuda de Alonso Martín, 1615, 2vo.

9. Por las excesivas fantasías milagreras que relata, esta biografía fue prohibida, a mediados del s. XVII por la Inquisición (TeófAnes EgIDo: «Hagiografía y estereotipos de santidad contrarreformista (La ma- 
ante su sorpresa por verse ahí: para que conste el cariño habido entre los dos hermanos, los cuales siempre estarán juntos. ${ }^{10}$

Así, con Francisco se introduce la figura del testigo: él lo es de lo que se muestra como visión de su hermano - plasmado en los grabados que fijan la escena-, evidenciando la importancia de esta figura, ${ }^{11}$ enlace entre lo terreno y lo divino y forma de dar realidad a la aparición: el testigo, conocido de los vecinos, garantiza la verdad de lo figurado. Propuesta de autenticidad con la imagen que aquí es doblemente engañosa ya que no hablamos de una visión de Juan sino de Francisco, en la carne de su hermano. Es Francisco quien se ve a sí mismo y no podría ser testigo de su propia visión.

El protagonismo interesado de los carmelitas como mentores de las imágenes que fijarían las visiones, se hace patente en el texto impreso de 1615 (Relación de un insigne milagro) que describe lo que calificará como milagrosa aparición; su autor es José de Jesús María (Martínez Medina). ${ }^{12}$ Ahí, el obispo Vigil de Quiñones aprueba en un texto las imágenes que la reproducen, a las cuales había integrado primero en el manuscrito que recoge los informes (Mss- 012738-024, p. 1212, con pintura de Diego Díez; y Mss- 012738- 001, p. 7, con un grabado anónimo) (Figs. 1 y 2). En ellas se fija el grabado del impreso (de Cornelis Boel) ${ }^{13}$ (Fig. 3), promoviendo su divulgación. ${ }^{14}$ La temprana intervención del obispo afirma el protagonismo eclesial postridentino y busca ajustar tal «visión» a un modelo útil: $:^{15}$ en el

nipulación de san Juan de la Cruz)», en Cuadernos de Historia Moderna, 25, 2000: p. 74). Ver a Egido para Francisco de Yepes y las biografías de S. Juan.

10. José de Velasco: Vida, virtudes y muerte del Venerable Francisco de Yepes, Valladolid: Juan Godinez de Milles, 1616.

11. Fernando Moreno Cuadrado: «Iconografía de los testigos de los procesos teresianos. A propósito de Adrian Collaert y la escenografía de la Capilla Cornaro», en Archivo Español de Arte, LXXXVII, 345, 2014, pp. 29-44.

12. José de Jesús María (Martínez Medina) y Vigil de Quiñones: Relación de un insigne milagro que Nuestro Señor obra continuamente en una parte de carne del Venerable Padre Fray Juan de la Cruz, Madrid: Viuda de Alonso Martín, 1615.

13. Boel, natural de Amberes, trabaja en Madrid a principios del XVII y alcanza prestigio grabando portadas (Juan Carrete Parrondo, Fernando Checa Cremades y Valeriano Bozal: Summa Artis, vol. XXXI, El grabado en España (Siglos XV-XVIII), Madrid: Espasa Calpe, 1987, p. 255).

14. Fernando Collar de CÁCeres: «En torno a la iconografía de san Juan de la Cruz. A propósito de su capilla-mausoleo», en Boletín del Museo e Instituto Camón Aznar, XIII, 1983, pp. 19-40. EMILIA MoNTANER: «La configuración de una iconografía: las primeras imágenes de San Juan de la Cruz», en Mélanges de la Casa de Velázquez, 27, 2, 1991, pp. 155-167. Ana Cristina Valero Collantes: «Una reliquia de San Juan de la Cruz custodiada en el Convento carmelitano de San José (Medina del Campo). Milagro transformado en arte», en De Arte, 8, 2009, pp. 47-54. Fernando Moreno Cuadro: «Origen andaluz de la Vera effigies de san Juan de la Cruz y su repercusión en Flandes y México», en Laboratorio de Arte, 25, 2013, pp. 347-370.

15. «Para la autoridad religiosa, el gran peligro de la experiencia visionaria residía precisamente en su carácter inmediato, en el hecho de permitir una relación directa con lo sagrado, sin el papel mediador de la Iglesia. Esta es la razón principal por la cual, a lo largo de todo el siglo XVI, la gran época del misticismo español, la iglesia consideró el ejercicio de las visiones como sospechoso, es decir, peligroso. Solo después del Concilio de Trento y sobre todo en el siglo XVII, la autoridad eclesiástica se afanará en manipular la experiencia visionaria de acuerdo con sus propios intereses. Para conseguir sus objetivos, necesitaba, en efecto, medios capaces de controlar la visión a fin de "re-presentarla" a la comunidad de fieles, pasándola 
impreso, además de autentificar tal milagro, se legitima una historia y sus imágenes y así se divulga de forma concreta, didáctica y mnemotécnica. Dice Vigil:

Hizimos que el dicho milagro y maravillosas apariciones se pintassen en este pergamino en la forma y manera que los testigos [...] declaran [...] y de nuestro orden y mandamiento pinto Diego Díez [...] sacandolas por la relacion que le fue hecha $[. .$.$] y de tres tarjetas originales, en las quales la primera vez se$ retrato y pinto el dicho milagro y dichas maravillosas apariciones, por Pedro de Soria [...] uno de los testigos [...] Para que por la vista de ojos se vean las dichas apariciones, las mandamos copiar y sacar de pintura en la manera que aquí van puestas [...] Y damos licencia[...] y las mandamos poner en este dicho processo [...] para que [...] se puedan sacar copias o trasuntos de pintura o escultura al modo y de la manera que nos lo avemos hecho sacar a Diego Díez [...] y poner en tres targetas pintadas al olio en una hoja de pergamino que de nuestro orden y mandamiento va puesta y inserta en el processo desta dicha causa despues de la dicha nuestra sentencia. ${ }^{16}$

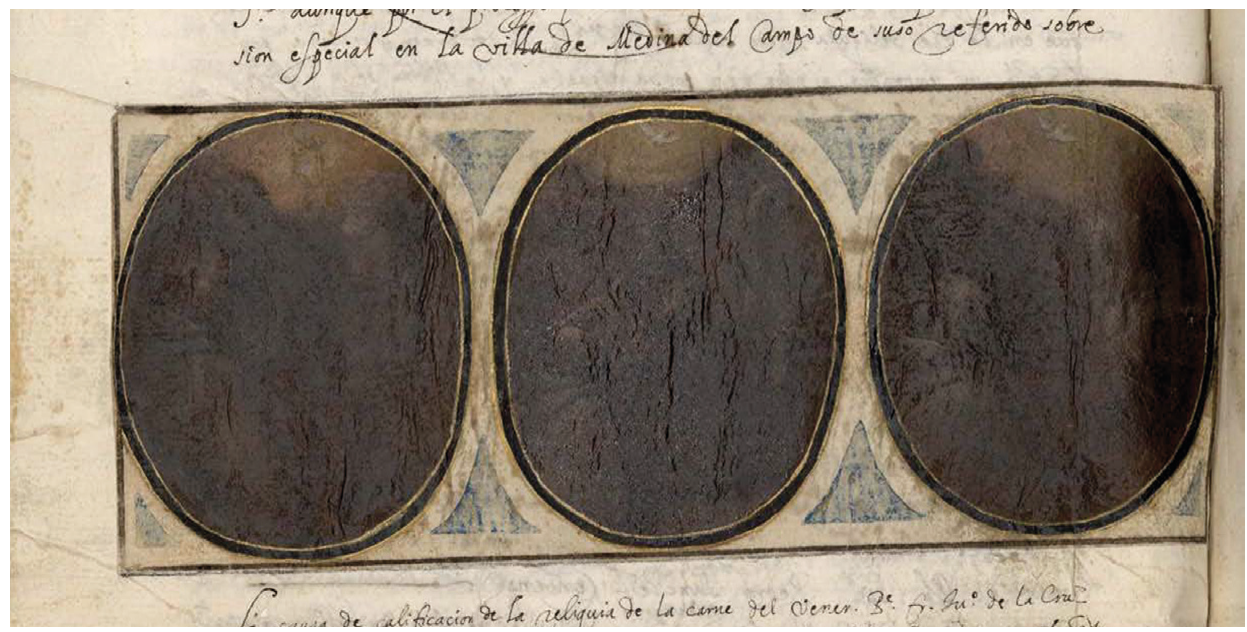

Fig. 1. Pinturas de Diego Diez, B. N. Mss- 012738- 024, p. 1212

previamente por el filtro de su propia autoridad. Uno de los medios de hacer pública la experiencia visionaria, que es, por esencia, íntima, era el cuadro de visión» (Víctor I. SтоіснітA: El ojo místico. Pintura y visión religiosa en el Siglo de Oro español, Madrid: Alianza, 1995). 1615.

16. José de Jesús María (Martínez Medina) y Vigil de Quiñones: Relación de un insigne milagro, 


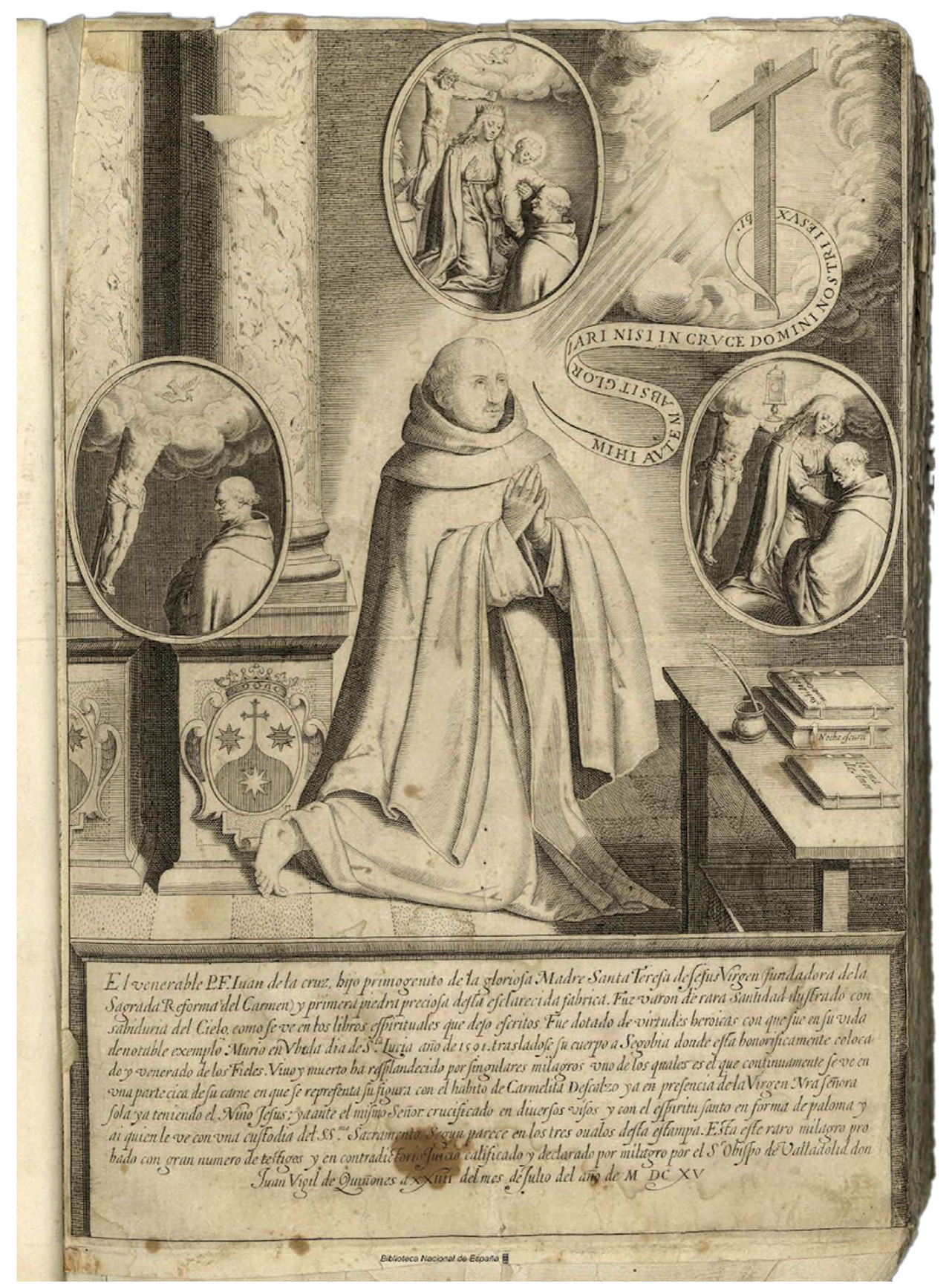

Fig. 2. Grabado anónimo, atribuible a Cornelis Boel y Diego de S. José. B. N. Mss- 012738- 001, p. 7 


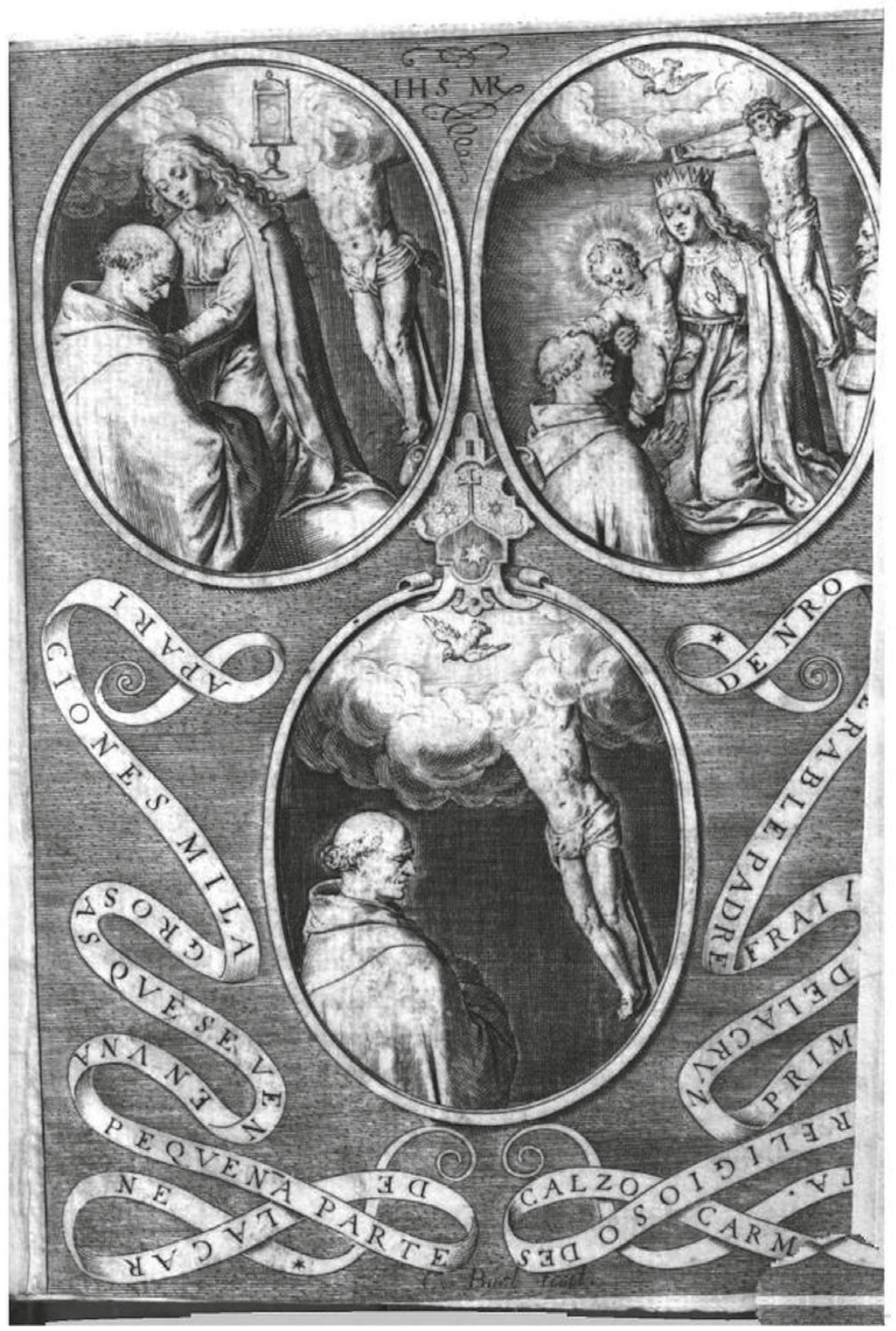

Fig. 3. Grabado de Cornelis Boel, En Relación de un insigne milagro, 1615 
La reliquia se hace famosa entre los vecinos de Medina del Campo y alrededores que comienzan a tener sus propias visiones, coincidiendo o no con las de Francisco. Y se multiplican las reliquias de Juan allí donde había vivido: de todas surgen visiones, aunque, como señalan altas instancias carmelitas, no todos los observadores las tienen sino solo aquellos que Dios quiere, cuando y como él decide. Esa misma cúpula tratará de aprovechar la explosión milagrosa para la canonización de Juan. Serán José de Jesús María (Martínez Medina) y Alonso de la Madre de Dios quienes organicen su causa y la del reconocimiento del milagro de la reliquia. Desde 1597 hasta 1628 se recopilan informes; ${ }^{17}$ de los testimonios, solo entre el 20 y el 30 por ciento, provienen de visiones directas; el resto citan de oídas. ${ }^{18}$

De los informes de las visiones en la reliquia de Francisco, deducimos su diversidad, constatada en dos listas que las sintetizan, cuya autoria y fecha -segura en una y muy probable en la otra-, es de Alonso de la Madre de Dios, en 1618, ya que él fue el «encargado de acreditar» ${ }^{19}$ tales relatos. La primera dice:

Aparece en la dicha carne Xpô crucificado como estava antes que espirase, aparece Xpô crucificado cubierto el rostro y el pecho con una nube, veese Xpô desnudo atado a una columna, veese un salvador hermoso y resplandeciente, veese Xpô crucificado muerto y atravesado con la lanza, aparece el santísimo sacramento en una custodia, aparece el espiritu santo en figura de paloma en un resplandor, aparece la virgen nuestra señora vestida del habito de carmelita con el niño jesus en los brazos el qual descolgandose dellos pone la mano sobre la cabeza del santo pe frai joan como acariciandolo, aparece la mesma madre de dios sin niño poniendo las manos como en el corazon al sto pe frai joan y el se muestra muy humilde y como agradecido a la virgen por tal favor, aparece un seraphim de extremada hermosura, veese san joseph como apadrinando al sto en estas apariciones, tambien se vee el benerable Francisco de yepes hermano del sto., muchos veen al santo pe fray joan en estas apariciones con diadema y resplandor de santo». La segunda lista casi la repite, pero esta descripción diseña mejor la escena: «aparece el santo de rodillas delante de Xpô crucificado que tiene el rostro cubierto con una nube y en medio de un resplandor una custodia en que se vee el santísimo sacramento (Mss-012738-014 y -023, B.N., pp. 667 y 1170).

A la concreción de estas listas, se pueden añadir más visiones. En todas, lo que se cree ver -en un proceso calificable de alucinación colectiva- surge del caudal de imágenes religiosas memorizadas, con las que se asocian. Por

17. Estos relatos, más de trescientos, están recogidos en los manuscritos Ms. 012730 y Ms 008568, ambos de la Biblioteca Nacional.

18. Luis E. Rodríguez-San Pedro Bezares: «Notas y comentarios. Tras las huellas de san Juan de la Cruz. Los contextos de una biografía», en Revista de Espiritualidad, 67, 2008, pp. 481-500.

19. TeÓfanes EgIDO: «Claves históricas para la comprensión de San Juan de la Cruz», p. 117. 
ello, los grabados del texto impreso definidor del milagro influyen en muchas posteriores. Otras difieren: las descalzas de Baeza, en su reliquia, ven un varón con un alfanje en la cabeza y piensan que es S. Ángelo, patrón de los carmelitas andaluces (Mss-012738-005, pp. 211-212). Las del convento de Calatayud, ven un varón con un cordero: S. Juan Bautista (Mss-012738-019, B.N., p. 915); una mujer llorosa y un joven triste: la Virgen y S. Juan en la Pasión; y una carmelita descalza que, por sus «lunares», identifican con Santa Teresa (Mss-012738-020, B.N., p. 960). También en Calatayud, dos prostitutas ven una mujer llorando, de largo cabello, con crucifijo y calavera: la Magdalena y, por su ejemplo, se convierten (Mss-012738-019, B.N., p. 915); un laico ve un sacerdote con sangre en el rostro y lo identifica con Pedro de Arbués, ${ }^{20}$ mártir aragonés cuya beatificación se promueve entonces (Mss-012738-020, B.N., p. 960). Los descalzos de Jaén ven a la Virgen con el Niño en un asno, llevado por S. José; un ermitaño barbado: Elías, fundador del Carmelo; una mujer en una cueva, con crucifijo y cilicio: la Magdalena; un joven rubio con corona: David; la Ascensión de Cristo e incluso la muerte, acontecida al poco a uno de ellos (Mss-012738-025, B.N. p. 1286), etc.

En todos los relatos, la asociación a formas recordadas muestra la efectividad de la imagen en transmitir y memorizar valores, de lo cual los dos José de Jesús María, Alonso de la Madre de Dios y el obispo Vigil de Quiñones, son conscientes. De estas visiones, al construir lo que sería idóneo para lograr la canonización de Juan, unas se relegan y se eligen las vinculadas a la reliquia de Francisco, cuya formulación figurada señaló Vigil. Recordemos que el primero que las reproduce es un pintor, Pedro de Soria, quien dice ser testigo de tales visiones; ${ }^{21}$ sus pinturas, aprobadas por Vigil, hoy se desconocen. De ellas, otro pintor, Diego Díez, hace una copia a instancias de Vigil -hoy borrosa (Fig. 1) $-^{22}$ que se incluye en la relación manuscrita de la testificación del milagro (Mss-012738-024, B.N., p. 1212). Consistiría en una reproducción de las tres escenas a destacar, con forma ovalada para adecuarse a la reliquia. Sobre ellas se elabora el grabado anónimo (Fig. 2) que acompaña el manuscrito del proceso (Mss- 012738-001, p. 7), quizás de Cornelis Boel, dirigido por Fray Diego de San José, secretario de José de Jesús María, General de la Orden; su factura sería anterior a 1616. Si nos fiamos de Velasco, ${ }^{23}$ tal secretario habría hecho el grabado original ${ }^{24}$ pero dada la maestría, similitud y

20. Pedro de Arbués, agustino, fue acuchillado en el cuello, en la Seo de Zaragoza, por judeo-conversos; se beatificó en 1662 .

21. José de Jesús María (Martínez Medina) y Vigil de QuiÑones: Relación de un insigne milagro, s.p.

22. Son tres óvalos de 75 por $186 \mathrm{~mm}$. Agradezco esta información (y su grandísima ayuda) a Mercedes Ramírez Îñiguez de la Torre, bibliotecaria de la Pública de Albacete.

23. José DE VELASCO: Vida, virtudes y muerte, p. 187.

24. Nos basamos para esta atribución en la noticia recogida por Velasco en la Vida de Francisco de Yepes (JosÉ DE VELASCO: Vida, virtudes y muerte, p. 187.). La primera edición de este libro es de 1616, por lo que el grabado debió de ser anterior. 
coincidencia de fecha con el grabado que veremos después, cabe pensar en Boel como autor material, aunque guiado intelectualmente por el carmelita. En el grabado aparece Juan orando, con los ojos abiertos, fijos en una cruz, en lo alto, entre nubes luminosas, cuyos rayos se dirigen e iluminan la figura arrodillada del santo. Entre Juan y la cruz, una filacteria (Mihi autem absit gloriari nisi $n$ cruce domini nostri Iesuxpi).$^{25}$ Notoriamente se muestra el pie derecho de Juan, descalzo, casi apoyando el nuevo escudo de la orden reformada que decora el podio de una columna toscana -con la connotación de fortaleza de este orden-, paralela a la figura del santo y que se halla junto a otra igual, incluido el escudo: el santo se equipara a una de esas dos columnas (la otra sería Sta. Teresa), en la reforma. La inscripción que va a los pies le llama "primera piedra preciosa desta esclarecida fabrica». Delante, una mesa con tintero, pluma y tres de sus libros: Llama de amor, Subida del Monte Carmelo y Noche oscura. Repartidos por la escena, los óvalos con las tres visiones seleccionadas de las que se habrían obtenido sobre su carne, descritas en una inscripción inferior -que no menciona la nube que cubre el rostro de Cristo en dos de ellas, ni la presencia del hermano en la otra.

Boel hace un grabado donde firma como fecit -autor de dibujo y grabado- el mismo año (Fig. 3), que se incluirá en el texto impreso, Relación de un insigne milagro, ${ }^{26} 1615$. Aquí solo se ven los tres óvalos, exactos a los anteriores pero girados: Boel sería el autor de los dos grabados. ${ }^{27}$ En este, el escudo del Carmelo reformado hace de nexo entre las tres escenas. Y junto a las iniciales de los nombres de Jesús y María, dos filacterias explican las visiones. $^{28}$

Como vemos, el dibujo nace de manos de quienes construyen la historia. Nos detenemos en las imágenes de las visiones. Aunque la justificación está en las supuestas visiones obtenidas por Francisco, todas las escenas se vinculan con episodios de la vida de Juan, descritos por sus biógrafos; de esta forma, la imagen sirve para pasar -ante los ojos de los devotos-, de la visión de Francisco, a la vida de Juan: olvidando a Francisco, Juan habría sido el protagonista de esas visiones en su vida. Ejemplo de ello es la posterior pintura de José García Hidalgo «Aparición de san Juan de la Cruz» ${ }^{29}$ (Fig. 4), donde solo se representa al santo ante la visión de un crucificado cuya cabeza desaparece entre nubes, sobre las que vuela el Espíritu Santo.

25. «Que esté lejos de mí gloriarme si no es en la cruz de nuestro Señor Jesucristo» (S. Pablo, Gal. 6, 14). 26. José de Jesús María (Martínez Medina) y Vigil de QuiNones: Relación de un insigne milagro.

27. Boel habría utilizado la impresión del grabado que hubiera hecho primero para, de ahí, abrir el cobre de la impresión del segundo, lo que implica el giro en las figuras de los óvalos.

28. Dicen: «Apariciones milagrosas QUe SE VEN EN UNA PEQUeÑa PARTE DE LA CARNE DE NRO VENERABLE PADRE FRAY JUAN De La CRUZ PRIMER RELIGIOSO DESCALZO CARMELITA».

29. En Segovia, en el convento de Carmelitas Descalzas. De fines s. XVII y primeros del s. XVIII. 


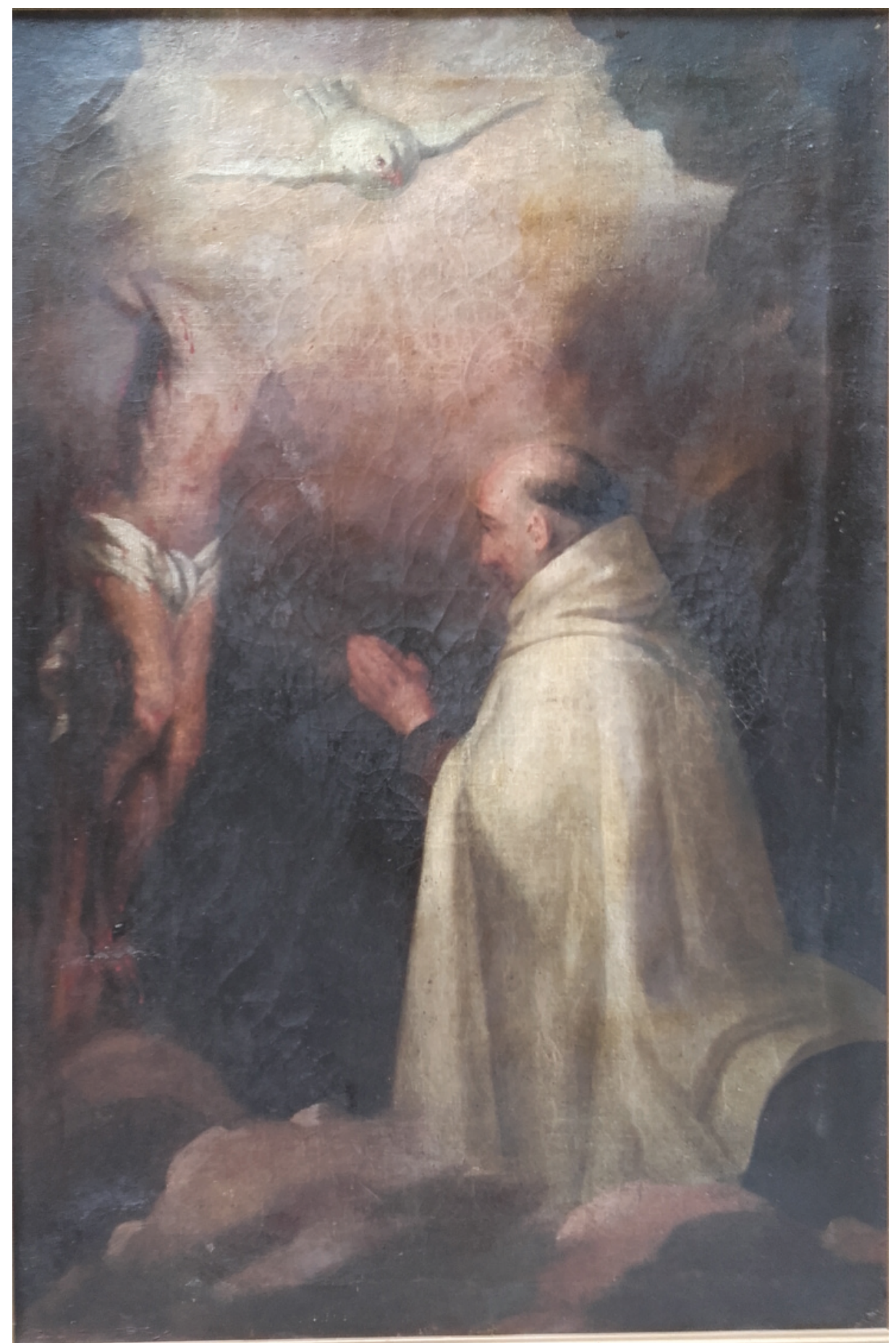

Fig. 4. José García Hidalgo, Aparición de San Juan de la Cruz. Óleo sobre lienzo, finales s. XVII y primeros del s. XVIII, Convento de Carmelitas Descalzas, Segovia 
En las escenas, las visiones se ubican en un lugar no real, con luces y sombras significantes. Juan tiene una visión a la que nosotros, gracias a la imagen, asistimos; recordemos que no a todos, al mirar la reliquia, Dios les concede ver tal aparición: la imagen -más allá de las elecciones divinas- la divulga. Juan, en un lado, quizás arrodillado, orante, recogido y con los ojos cerrados en las dos ocasiones en las que aparece el cuerpo de Cristo entre nubes, y abiertos en la otra, lleva el hábito carmelita descalzo, cuya capa también porta, significativamente, la Virgen. Esta aparece arrodillada en una nube, en un nivel superior, reconfortando al santo, como se le habría aparecido en la cárcel de Toledo, según sus biógrafos. En otra escena, la Virgen lleva al Niño en sus brazos; este acaricia la cabeza de Juan con una mano y con la otra se sujeta en la nuca de la madre, uniendo los tres personajes. Solo aquí Juan tiene los ojos abiertos contemplando, en escala, al Niño, la Virgen y un Cristo de tamaño inferior pero más elevado que los anteriores, al fondo, en extraña duplicación de la figura de Jesús. Y en lo alto, sobre una nube, el Espíritu Santo.

El crucificado aparece en las tres escenas. Según sus biógrafos, en Ávila, en el momento de expirar se le habría aparecido a Juan, quien lo habría contemplado desde arriba, en complicada perspectiva que luego plasmaría en un dibujo (Fig. 5) del que alaban la destreza. ${ }^{30}$ Evidencia del poder impactante dado a la imagen en estos momentos, que se observa también al describir la pintura origen de la otra aparición de Cristo a Juan, en Segovia, ${ }^{31}$ portando la cruz. Pero ninguno de estos contactos entre Juan y Cristo lo habrían mostrado con la parte superior del cuerpo oculto entre nubes luminosas, como se figura en dos de estas visiones: junto a su madre, cuando reconforta al santo, o frente a Juan, con el Espíritu Santo en la nube que le cubre. Nubes brillantes, ámbito celeste, que contrasta con el fondo oscuro del grabado, lugar habitado por el santo.

30. Jerónimo de San José dice: «Estava orando el Venerable varon y contemplando en los dolores que su divina Magestad avia padecido en la Cruz, aquel divino rostro afeado, su lastimera figura, y el descoyuntamiento de todo su sagrado cuerpo [...] vio subitamente delante de los ojos lo que se le representava dentro de su alma [...] Quedole aquella figura tan impressa que despues a solas tomando una pluma, la dibuxó en un papel con solas unas lineas [...] Tres cosas [...] son dignas de ponderación en este dibuxo. La primera, la posición en que se le represento Cristo Señor nuestro, y la que tenia el Venerable varon quando le vio. La segunda, el artificio del dibuxo. La tercera, la devocion que representa y causa. Quanto a la posicion [...] parece averle visto el Venerable Padre estando superior al Crucifixo [...] Mas porque assi, y no buelto al mismo Venerable Padre? Podriase creer aver sido para representar con aquel escorço a sus ojos una figura mas lastimosa y descoyuntada, de lo que pareciera derechamente. Acerca del Artificio, quantos saben del en la pintura han admirado que lo mas dificultoso della, que es la perspectiva en escorços, la huviesse executado tan diestra y fácilmente quien no huviesse, y por muchos años exercitado el arte de pintar» (JERÓNIMO DE San José: Historia del Venerable Padre Fray Juan de la Cruz, Madrid: Diego Díaz de la Carrera, 1641, pp. 186-188). F. Sánchez Cantón, subraya la emoción que transmite tal dibujo, su habilidad, y añade: «es en su siglo el primer caso español de Crucifijo con cuatro clavos, innovación o retorno que se fechaba entre nosotros seis años después de la muerte de San Juan de la Cruz, quien se inspiraría en las revelaciones de Santa Brígida» (F. J. SÁnchez CAntón: «¿Cabe hablar de S. Juan de la Cruz y las artes?» en Escorial, Revista de Cultura y Letras, 25,1942, p. 311). Interesante apreciación de los cuatro clavos, en la que se basa el grabado de Herman Panneels (original de Amberes, trabaja en Madrid entre 1638 y 1650), en 1641, para ilustrar la biografía de S. Juan hecha por Jerónimo de S. José.

31. El «milagro de Segovia» es relatado por sus biógrafos. 


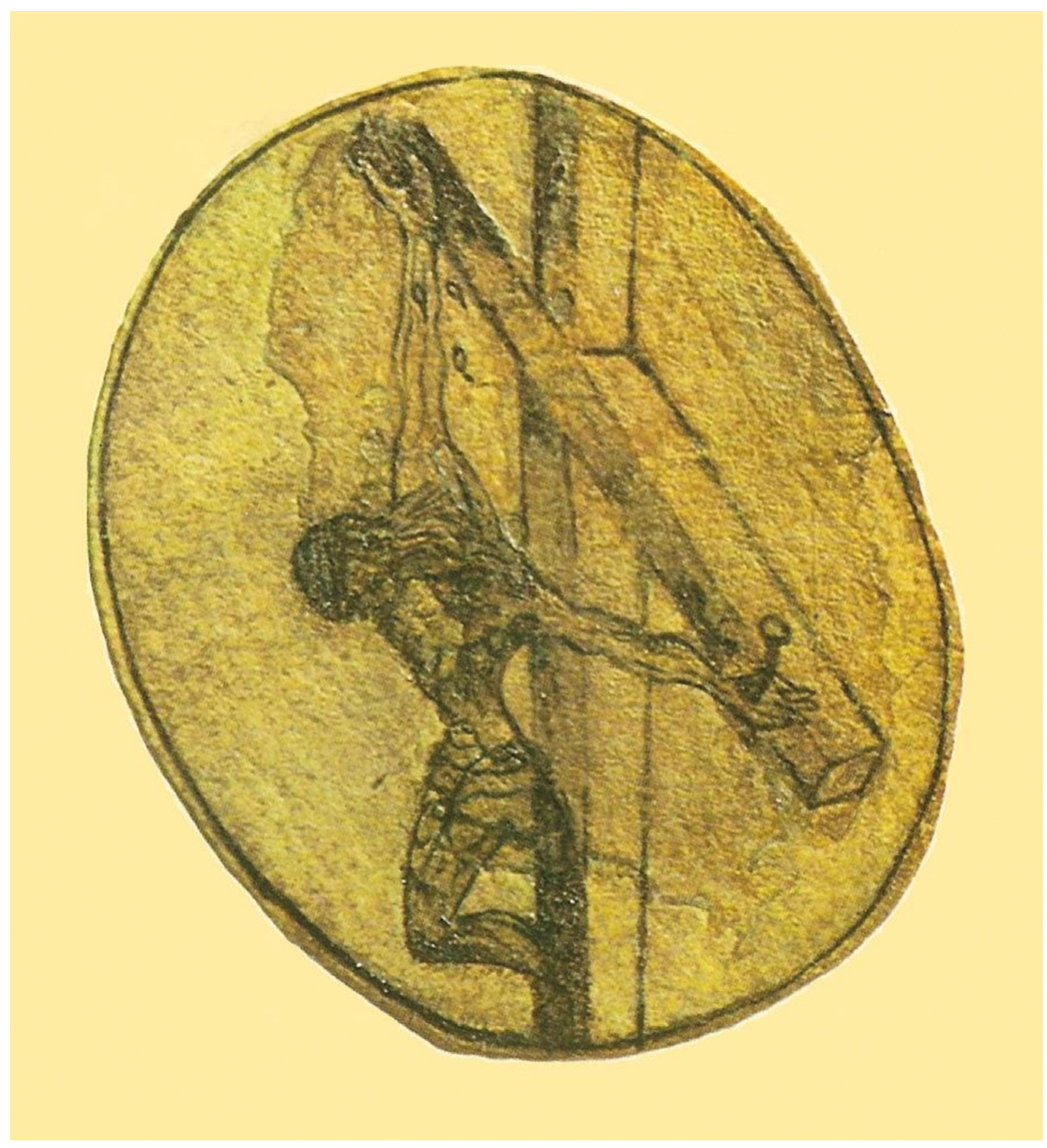

Fig. 5. Juan de la Cruz, Dibujo de Cristo crucificado, 1572-1577, 57×47 mm, Monasterio de la Encarnación, Ávila

El Espíritu Santo como paloma en la vida de Juan se argumenta al asegurar que una paloma le acompaña de convento a convento, sin ir con otras ni comer, identificándose como tal Espíritu, continua inspiración en sus escritos.

En otra escena, la nube que cubre a Cristo contiene una custodia. Esta se justifica por testimonios de cómo, al decir misa, la custodia en sus manos desprendía resplandor hacia Juan, admirando a los presentes y denotando su santidad (Mss-012738, B.N.). 
La otra figura que aparece y solo en la escena más completa (Virgen con Niño, Cristo descubierto y Espíritu Santo) es la de Francisco, testigo asombrado de la visión de su hermano. Señalamos cómo solo sería testigo imposible de su propia visión.

La figura más interesante y sorprendente es la de Cristo cubierto por una nube brillante: ¿en qué testimonios se apoya?, ¿qué significa? Solo hablan de ella las dos listas de imágenes mencionadas, de la mano de Alonso de la Madre de Dios. La excepción es, en el mismo manuscrito, el testimonio de fray Martín de San Joseph que habla de «un Christo crucificado hasta los hombros cubierto rostros y braços como con una nuve» (Mss 012738, B. N., p. 454); pero dice conocer la «Sentencia de calificación de un continuo y extraordinario milagro», de Vigil (Mss-012738-024, pp.1201-1216, B.N.), 1615, y su descripción es fiel a los grabados que aquí se incluyen. Por el contrario, tal tipología de Cristo que no incluyó su hermano Francisco, tampoco habría sido citada por Vigil, ni en dicho manuscrito ni en el impreso. ${ }^{32}$

El impreso tiene una introducción que hace el P. General José de Jesús María; ahí cuenta la historia de la reliquia y de las escogidas apariciones, incluyendo a Francisco. Él mismo dice haber visto «al venerable padre y el Christo y la palomica» y, en otra ocasión, con la Virgen y el Niño, como lo ven «los mas»; y lo mismo vio su secretario Diego de S. José. Pero, además, añade el importante testimonio del pintor Pedro de Soria: «Christo en la cruz desde los brazos abaxo, cubierto lo demas del rostro con un resplandor o nuve clara que se ve en la parte superior»; ${ }^{33}$ por ello se le encargó que pintase su visión. Recordemos que así se hizo la primera pintura, de la que se habrían hecho copias, y probablemente esta es la descripción más temprana de Cristo entre nubes, inicio de una iconografía, guiada por el P. General, José de Jesús María y por Alonso de la Madre de Dios; como hemos visto, ambos textos, manuscrito e impreso, incluyen las imágenes grabadas de este Cristo oculto.

Buscamos referencias a tal tipología de Cristo en las biografías ${ }^{34}$ de Juan, todas de manos carmelitas y posteriores a la calificación del milagro de la reliquia en $1615 \mathrm{y}$, por tanto, influenciadas por sus textos e imágenes. Curiosamente, la primera biografía es la que va incluida en la de su hermano Francisco, escrita por Velasco. ${ }^{35}$ Aquí se relatan las visiones de Francisco: Juan con hábitos y capa del Carmen, a los pies de la Virgen -con la misma capa- y

32. José de Jesús María (Martínez Medina) y Vigil de QuiÑones: Relación de un insigne milagro.

33. José De Jesús MARía (Quiroga): Historia de la vida y virtudes del venerable P. F. Juan de la Cruz, Bruselas: Juan de Meerbeeck, 1628, s.p.

34. Sobre el género hagiográfico en los siglos XVI y XVII en España, y su papel en la construcción de las figuras de los santos, ver: Teófanes EgIDO: «Claves históricas para la comprensión de san Juan de la Cruz».

35. José DE Velasco: Vida, virtudes y muerte del Venerable Francisco de Yepes, Valladolid: Juan Godinez de Milles, 1616. (1 $1^{\text {a }}$ ed: $1616 ; 2^{\text {a }}$ ed: $1617 ; 3^{\text {a }}$ ed: 1624$)$. 
el Niño Jesús en sus brazos; y, a partir de un día, el propio Francisco. ${ }^{36}$ Una vez muerto, siguen viéndose las «quatro personas», las mencionadas, aunque hay quien ve también al Espíritu Santo, Sta. Teresa y Cristo (en la cruz, como Ecce Homo, atado a la columna o en la Oración del Huerto), «como por una información consta, que se hizo el año 1615 ante el [...] Vicario General de Medina y su tierra, a petición de nuestros padres descalços carmelitas». ${ }^{37} \mathrm{En}$ ningún momento se menciona al crucificado envuelto en la nube. El mismo Velasco incluye su propia visión. ${ }^{38}$ Añade que vieron la reliquia el General José de Jesús María y su secretario, Diego de San José, pero no dice qué. No obstante, dicho secretario, para «que las maravillas de Dios saliessen a luz [...] con licencia y bendición de dicho Padre General [...] sacó en estampa estas figuras que se ven en el relicario» que habrían dado lugar a tres estampas distintas, ${ }^{39}$ reflejo de las tres visiones seleccionadas. Por ello incluimos a Fray Diego de San José en la primitiva elaboración de las imágenes y en la autoría (quizás solo intelectual) del grabado anónimo (Fig. 2) del manuscrito del proceso (Mss- 012738- 001, p. 7, B. N.).

En el año 1618 nos encontramos con dos breves biografías. Una es la de José de Jesús María (Quiroga) ${ }^{40}$ en la primera publicación de la obra literaria de S. Juan (Alcalá, 1618, reimpreso en Barcelona en 1619): Obras espirituales que encaminan a una alma a la perfecta unión con Dios. Tal publicación se hace a instancia del P. General José de Jesús María (Martínez Medina), ${ }^{41}$ quien firma la dedicatoria. Al ser posterior al impreso de la proclamación milagrosa de las apariciones, Quiroga repite lo ahí descrito con un impersonal «se ven». Incluye la mención al Cristo oculto:

36. Como señala Velasco en la edición de 1617, Francisco se ve de dos formas: «Antes no se vía mas de la cabeça y ahora se ve todo el cuerpo, que esta de rodillas delante de la Virgen santissima». En el primer caso, aparecía detrás de su hermano Juan, en el lado derecho (José DE VelasCo: Vida, virtudes y muerte del Venerable Francisco de Yepes. Edición de Ana Díaz Medina, Valladolid: Junta de Castilla y León, 1992, p. 17)

37. José de Velasco: Vida, virtudes y muerte del Venerable Francisco de Yepes, 1992, p. 183.

38. Díaz Medina, al presentar la edición de 1616, recoge que, en la de 1617, Velasco añade al margen: «Lo que ve el autor: A mi se me muestra un religioso del Carmen como hermitaño y sin capa, entre unos riscos, metido en una cueva, haciendo penitençia, en oracion, como arrobado... en cosa tan pequeña... se distinguen los ojos y barbas, largas y rubias, y las demás facciones del rostro, como se pudiera ver en una pintura grande. Tambien se muestra una Paloma blanca, tendidas las alas, y los ojos, pico y pies con distinción» (José de Velasco: Vida, virtudes y muerte del Venerable Francisco de Yepes, 1992, p:183).

39. Velasco añade: «Tres diferencias de estampas destas andan inxeridas en la información que se ha dicho, de la qual se han sacado y impresso muchos traslados que andan repartidos por muchas partes de España y por otros Reynos. Esta buena obra y virtuoso trabajo se debe a este religioso padre, porque no quedasen en tinieblas cosas tan raras y admirables» (José DE Velasco: Vida, virtudes y muerte del Venerable Francisco de Yepes, 1992, p.187)

40. Obras espirituales que encaminan a una alma a la perfecta unión con Dios. Por el venerable P. F. Juan de la Cruz [...] Con una resunta de la Vida del Autor y unos discursos por el P. F. Diego de Jesús [...]Impresso en Alcalá por la Viuda de Andrés Sánchez Ezpeleta. Anno de MDCXVIII. (En 1619 se hace una reimpresión en Barcelona, por Sebastian Cormellas). La «resunta» lleva el título Relación sumaria del Autor deste libro, de su vida y virtudes, y es de Quiroga, aunque sale anónima. (Fortunato Antolín: José de Jesús María (Quiroga), pp. 22 y 127).

41. Fortunato Antolín: José de Jesús María (Quiroga), 1991, pp. 21. 
Christo [...] crucificado, ya entero todo el cuerpo, ya metido el rostro en una nube: y la Virgen [...] con el Abito del Carmen y el Niño Jesus en los braços que estiende una mano hazia el mismo Venerable Padre, el qual se ve con su abito como puesto de rodillas, y su hermano Francisco de Yepes a un lado; el Espiritu Santo en forma de paloma, y una Custodia del Santissimo Sacramento. ${ }^{42}$

La otra biografía de 1618 es de Jerónimo de San José (Ezquerra de Roza), autor de las biografías tercera y sexta. Esta de 1618 forma parte de otra impresión de la obra literaria de Juan ${ }^{43}$ que no se realiza hasta $1629^{44}$ y $1672,{ }^{45}$ ambas en Madrid. La biografía, Dibuxo del Venerable Varón Fray Ivan de la Cruz, no tiene ninguna mención a Cristo oculto; son apariciones de

Christo Señor Nuestro, de su Madre Santissima, del Espíritu Santo en figura de Paloma, del Santissimo Sacramento, de los Ángeles y Serafines y de innumerables Santos [...] del mismo Venerable fray Juan arrodillado ante Christo N. S. y la Sacratissima Virgen su Madre. ${ }^{46}$

Pero existe un volumen facticio en la Biblioteca Nacional (Ms 6632) donde se incluye el texto impreso del Dibuxo (Madrid, Viuda de Pedro de Madrigal, 1629) junto a manuscritos sobre Juan, del mismo autor y época. Y entre ellos aparece un grabado de K. Knyf ${ }^{47}$ (quien firma feci, es decir, pintó y grabó) (Fig. 6), sin fecha, donde imita, en inferior calidad, los tres óvalos conocidos, incluyendo a Cristo oculto. Su originalidad radica en identificar con el nombre a Juan y su hermano, y en dos cartelas que incluyen citas bíblicas alusivas, ${ }^{48}$ cuya rareza requiere un mentor que pudo ser Fray Jerónimo. Añade el escudo

42. JUAN DE LA CRUZ: Obras Espirituales que encaminan una alma a la perfecta unión con Dios. Barcelona: Sebastián Cormellas, 1619.

43. Obras espirituales del Venerable y Mistico Doctor Fray Juan de la Cruz, Primer Descalço y Padre de la Reforma de nuestra Señora del Carmen. Sobre las primeras publicaciones de la obra literaria de S. Juan: Eulogio de la Virgen del CARMen: «Primeras ediciones del Cántico Espiritual», 1967, pp. 3-48.

44. Fortunato Antolín, José de Jesús María (Quiroga), 1991, pp. 83

45. JuAn de la Cruz: Obras del Venerable Padre Fray Juan de la Cruz, Madrid: Bernardo de Villa Diego, 1672. A costa de la Viuda de Juan de Valdés. Aquí se incluye el Dibuxo de Jerónimo de S. José, y los Apuntamientos de Diego de Jesús.

46. Jerónimo de SAN José: «Dibuxo del venerable varón Fray Juan de la Cruz», en JuAn de LA Cruz, Obras del Venerable Padre Fray Juan de la Cruz, Madrid, Bernardo de Villa Diego, 1672, p. 36.

47. Knyf es un grabador «posiblemente holandés que trabaja en Madrid y colabora con Popma y otros flamencos» (Blanca García Vega: El grabado del libro español. Siglos XV-XVI-XVII, Valladolid: Diputación Provincial, I y II, 1984, p. 90). Precisamente Popma hace el grabado de S. Juan de la Cruz frente al Cristo del milagro de Segovia, para el libro Dibuxo del venerable varón, de Jerónimo de S. José, Madrid, Francisco Martínez, 1629.

48. Ut et vita Iesu manifestitur in carne nra. mortali («Para que la vida de Jesús se manifieste también en nuestra carne mortal»), 2, Corintios 4,11; Quam multipliciter tibi cara mea («De muchas maneras mi carne [te necesita] a ti»), Salmo 62, 2 (Vulgata). 
carmelita reformado y una inscripción que explica el carácter milagroso de las visiones.

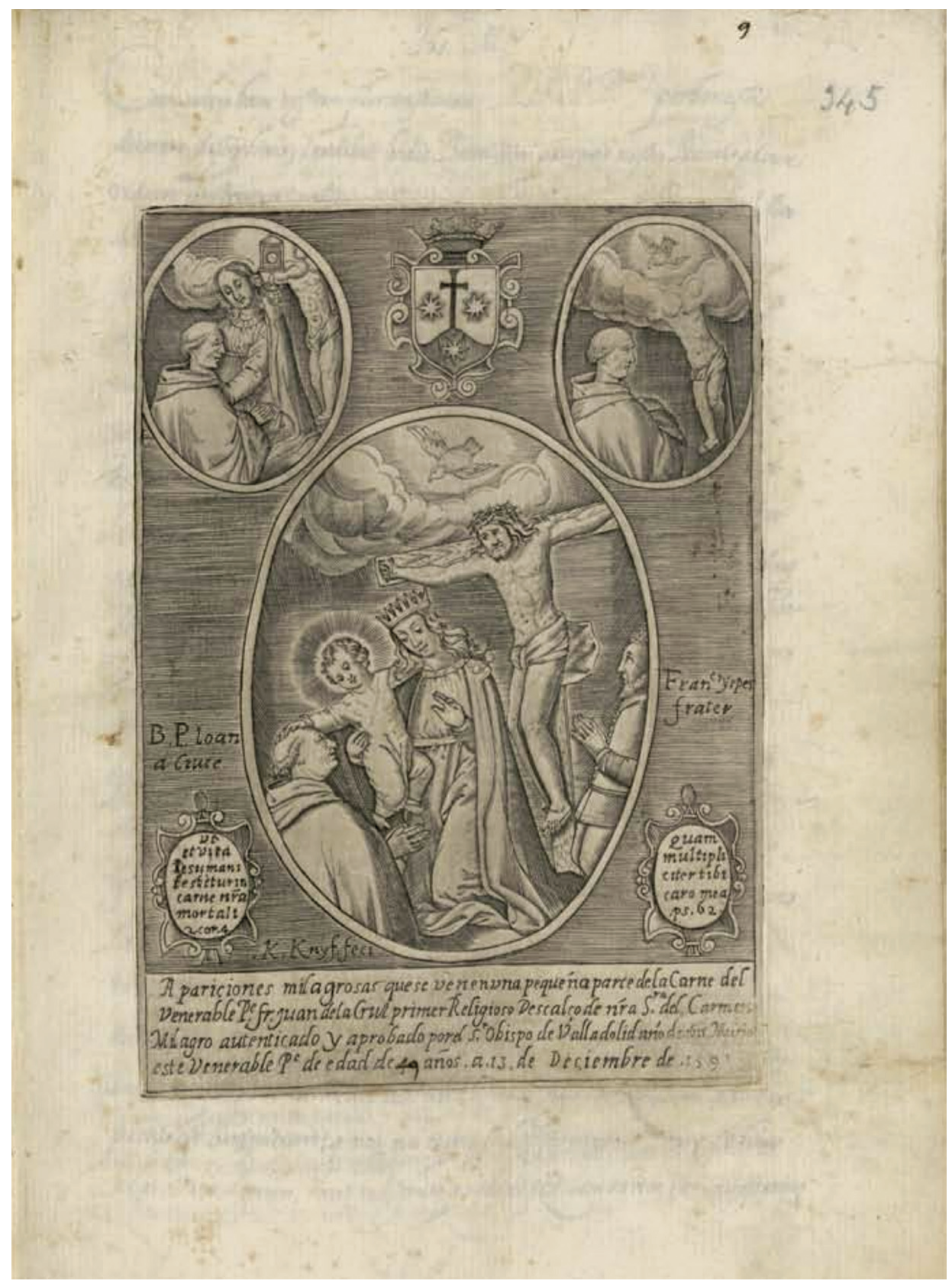

Fig. 6. Grabado de K. Knyf, en Dibuxo del Venerable Varón Fray Ivan de la Cruz, 1629 
Jerónimo de San Joseph es también autor de la que sería la sexta biografía, con un texto de 1641. Aquí sí se habla de Cristo en la cruz cubierto por la nube: realmente, lo que hace es describir los grabados que conocemos junto con imágenes de las listas de Alonso de la Madre de Dios. A la visión de Francisco:

Vio en el mismo pedacito de carne a la Virgen Sacratissima nuestra Señora vestida con el habito del Carmen, con el niño Jesus en sus braços, echado el bracito izquierdo sobre el cuello de su Madre, estendiendo el cuerpecito, y el otro braço hasta que llegava a poner la mano derecha sobre la cabeça de nuestro Venerable Padre.

Añade las de otras personas:

Unos vian en ella a Cristo nuestro Redentor crucificado: otros al niño Jesus en los braços de su Santissima Madre: otros al Venerable Padre hincado de rodillas delante de un Crucifixo, cubierto el rostro con una nuve y lo demas del cuerpo descubierto [...] Cristo [...] se muestra tambien de muchas maneras [...] como niño en los braços de su Santissima Madre [...]desnudito en los braços del Venerable Padre, que hincado de rodillas le esta besando los preciosos pies [...] sentado el Niño en una nuve, con una corona de oro en la mano que se la va a poner en la cabeça al Venerable Varon [...] sentado el Niño en el braço izquierdo del Venerable Padre, y el con el derecho abraçando al precioso Niño [...] Aparece assimismo [...] la Imagen de nuestro Salvador, de la edad que era [...] quando murio [...] muy hermoso y resplandeciente $[. .$. [o] en diferentes passos de su Sagrada Passion[...] Otras veces se ven muchos Angeles [...] un Serafin. ${ }^{49}$

De cronología anterior, la cuarta biografía apareció en Amberes anónima, en 1625. Se atribuye a Alonso de la Madre de Dios (Martínez, el Asturicense), gran protagonista de la causa de Juan en la que «fue postulador en casi todos los procesos de las Informaciones in genere (1614-1618)»; ${ }^{50}$ recordemos su autoría en las listas de las visiones en la reliquia de Francisco. En esta vida ${ }^{51}$ y

49. Jerónimo de SAn José: Historia del Venerable Padre Fray Juan de la Cruz, 1641, pp. 896-898. Esta biografía se incluye, resumida, en dos ediciones de la obra literaria de S. Juan, en el s. XVIII, antes y después de su canonización: Obras espirituales que encaminan a una alma a la mas perfecta union con Dios, en transformacion de amor. Por el Extatico, y Sublime Doctor Mystico, el Beato Padre San Juan de la Cruz, [...] En Sevilla, por Francisco de Leefdael [... 1 1703. Esta obra va muy ilustrada con grabados de Matías de Arteaga y Juan Pérez. El grabado que representa las apariciones en la reliquia reproduce la escena en la que aparecen todos los personajes, con Cristo sin cubrir y Francisco. La siguiente obra a la que me refiero, de idéntico nombre, se imprime «En Pamplona: Por Pasqual Ibañez Impressor, año de 1774».

50. Fortunato Antolín: José de Jesús María (Quiroga), 1991, pp. 50.

51. Summa de la vida y milagros del Venerable Padre Fray Juan de la Cruz primer Descalzo de la reforma de nuestra Señora del Carmen, sacada de las informaciones que se an hecho para su Canonizacion. En Amberes. En casa de Pedro y Juan Belleros. MDCXXV. 
sobre dichas visiones, aunque, como señala, bebe de las informaciones de la causa y de los grabados de esta, no incluye ni a Francisco ni a Cristo oculto:

Las Tres personas de la santissima Trinidad [...] juntas [...] [o] separadas [...] la santissima cruz [...] la corona de espinas [...] los clavos [...] las cinco llagas [...] la Virgen [...] con Niño el qual estendiendo la mano derecha sobre la cabeça del santo Padre parece le esta como acariciando [...] [y a la Virgen] que con sus manos le esta [...] trabando la capa por la parte superior [...] Angeles, Cherubines [...] Profetas, Apostoles y otros santos. ${ }^{52}$

Según Antolín, entre 1629 y 1631 se completaría el manuscrito de la vida de Juan, del mismo Alonso, ahora extensa; habría permanecido así (Ms. 13.460 de la Biblioteca Nacional) hasta la edición que hace Antolín en 1989.53 Tal manuscrito, Vida, Virtudes i Milagros del Sancto padre Fray Ioan dela Cruz, Maestro i Padre dela reforma dela Orden delos descalzos de nra señora del Monte Carmelo, incluye un magnífico grabado rectangular (Fig. 7), muy parecido al óvalo de la escena de Juan, Virgen, Niño, Espíritu Santo y Cristo descubierto, pero sin el hermano, en coherencia con lo descrito en la Summa de la vida. Va firmado con C. de Mallery excudit, ${ }^{54}$ lo que evidencia la relación con Amberes, origen y residencia de este grabador que aquí también sería editor de la estampa. En el texto, Alonso describe las visiones tenidas en las reliquias desde el momento originario:

Mirando el venerable Francisco la carne de su hermano, viole en ella tan al natural [...] de rodillas con las manos puestas ante la Virgen [...] vestida del hábito y manto de Carmelita, de rodillas sobre una nube con el Niño Jesús vestido en los brazos, el cual abrazando con el bracito izquierdo el cuello de su Madre y alargando el cuerpo y bracito derecho ponía sus manos sobre la cabeza del santo padre fray Juan.

52. Summa de la vida y milagros, 1625 , pp. 48-50.

53. Alonso de la MAdre de Dios (Martínez): Vida, virtudes y milagros del Santo Padre Fray Juan de la Cruz Maestro y Padre de la Reforma de la Orden de los Descalzos de Nuestra Señora del Monte Carmelo, Edición de Fortunato Antolín, Madrid: Ed. Espiritualidad, 1989.

54. Karel van Mallery (Amberes, 1571 - ca. 1635), famoso y prolífico grabador; muchos de sus trabajos se vinculan a ámbitos jesuíticos. 


\section{Vida}

Virtudes, i. Milagros del Sancto padre

Fray Loan dela Crus

Maestro, i Padre dela reforma dela orden delos descalzas de wráa sunóraw delllente Carmelo. Tomo quinto.

Porelpadre fay Alonso dela madrede Dios Asturiconse, delamesmas orden
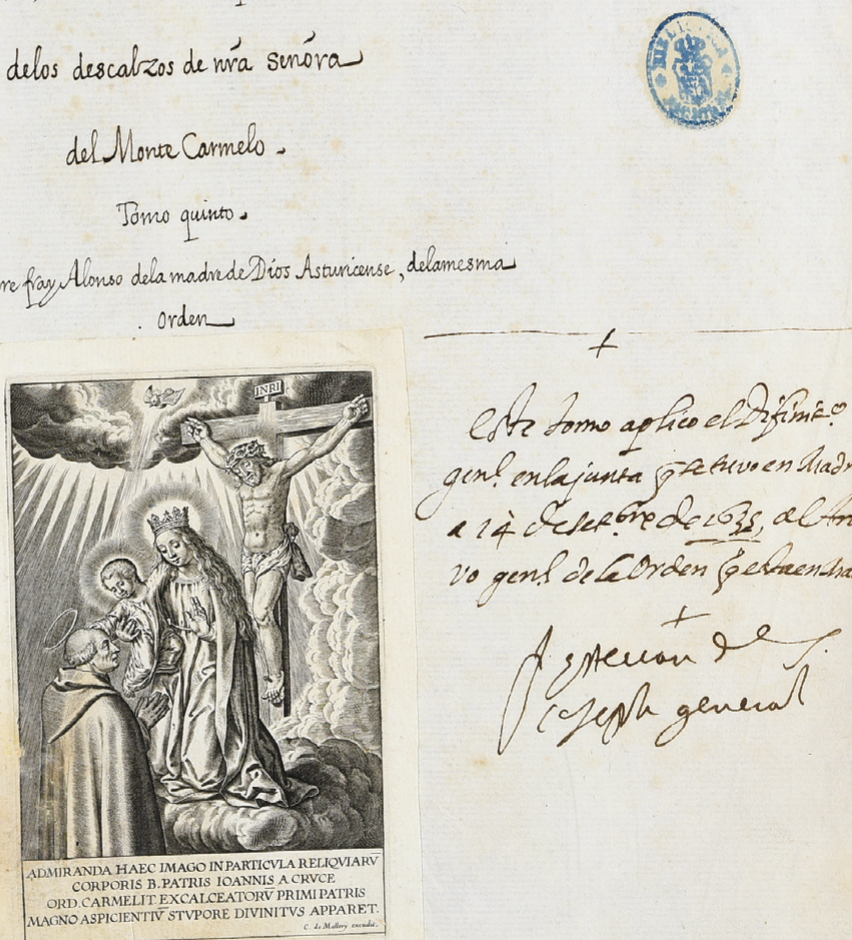
aenl enlajunta pective en hiadrio

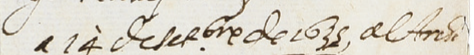
vo gend de Ceorden gementhain distecuar es general

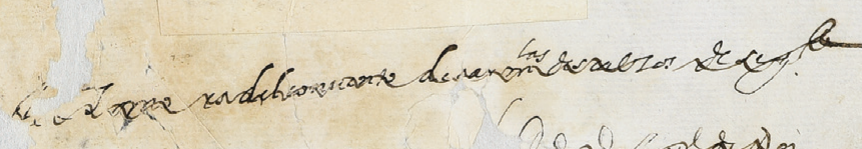

$$
\begin{aligned}
& \text { ar- Renoldeda } \\
& \text { ind } 2
\end{aligned}
$$

Fig. 7. Grabado de C. de Mallery, Vida, Virtudes i Milagros del Sancto padre Fray Ioan dela Cruz, Ms. 13.460 de la Biblioteca Nacional 
Y añade distintas visiones de otras personas, nunca de él mismo; así, incluye la del «santo de rodillas ante Cristo nuestro Señor crucificado, cubierto desde el pecho arriba con una nube, mostrando los brazos y desde el pecho abajo descubierto»..$^{55}$ Observemos el lógico parecido de estas descripciones con las que codifica el propio Alonso, en las listas referidas (Mss-012738-014 y -023, B.N., pp. 667 y 1170), hechas para el informe sobre las reliquias, en el proceso incoado para la beatificación. Significativamente, Alonso añade: «Y esto veían muchos. Otros veían otras cosas tales y muchos y los más, no veían cosa alguna». ${ }^{56}$ Finaliza poniendo la siguiente reflexión en boca de un jesuita, testigo de las visiones; estas no habrían sido:

ociosas sino que cada una de ellas tenía sobre la apariencia que se veía una significación espiritual de misterio secreto y escondido, el cual descubriría Nuestro Señor a los que con intención sencilla miran las obras de Dios y veneran en ellas la profundidad de su sabiduría y no intentan medirla con su corto juicio. ${ }^{57}$

Así Alonso advierte a posibles críticos y señala el carácter metafórico «a lo divino», de las mismas.

Observaciones semejantes vemos en la quinta biografía, de José de Jesús María (Quiroga). Fue publicada sin los permisos requeridos en Bruselas, 1628, lo que le causó problemas. Aquí se da una lista de las figuras aparecidas en la reliquia, citando las de la visión de Francisco (Juan arrodillado y orante ante la Virgen con el Niño, esta y el santo con el hábito del Carmen), a las que añade otras: una custodia, Francisco, S. José, Sta. Teresa y Cristo. Este, «unas veces era con su cruz, en figura entera y otras sin cruz y cubierta con una nube la cabeça y los braços, y en cima de la nube el Espíritu Santo en forma de paloma echando rayos; y esta segunda ymagen del Christo era mas ordinaria». ${ }^{58}$ Es evidente la referencia a los grabados conocidos, en especial al describir a Cristo envuelto en la nube, donde la cruz apenas se dibuja; y el interés por afirmar la abundancia de esta fórmula. Recoge también los casos de apariciones en otras reliquias que constan entre los tes-

55. Alonso de la Madre de Dios (Martínez): Vida, virtudes y milagros del Santo Padre Fray Juan de la Cruz, 1989, p. 606.

56. Alonso de la Madre de Dios (Martínez): Vida, virtudes y milagros del Santo Padre Fray Juan de la Cruz, 1989, p. 606.

57. Alonso de la Madre de Dios (Martínez): Vida, virtudes y milagros del Santo Padre Fray Juan de la Cruz, 1989, p. 606.

58. José de Jesús María (Quiroga): Historia de la vida y virtudes del venerable P. F. Juan de la Cruz, 1628, p. 973. De este libro se hace una reimpresión con mínimas variaciones y otro título, más tarde, para apoyar su canonización: Hechos heroycos de la portentosa vida y virtudes de N. [...] Padre S. Juan de la Cruz [...]Doctrina acreditada con obras, que de la divina contemplación delineo su pluma. [...] declara [...] F. Joseph de Jesus María, Historiador primero del Carmen Reformado [...] les ofreze el R. P. Fr. Juan de la Resurreccion, [...] Con privilegio en Málaga: En la Imprenta de Juan Vazquez Piedrola, Impressor y Librero [...] Año de 1717 . 
timonios para la canonización: Salvador, Ecce Homo, Elías, Juan Bautista, Magdalena, Verónica, serafines... e incluye curiosos casos. Destacamos el de Juan Bautista de Alvarado, de Jaén, cuya visión es conocedora indudable de los grabados vistos y refuerza la imagen del Cristo cubierto -incluida la casi desaparición de la cruz-: vio «un Christo crucificado solo el cuerpo sin ver cruz y mostravase solo desde los pechos hasta los pies [...] desde el pecho arriba (que se entiende cabeça y braços) estava cubierto con una nube sobre la qual vio un Cherubin». Y, como conociendo la importancia del dato, añade: «los pies [...] estavan clavados uno sobre otro». ${ }^{59}$ Tal observación, fiel a dichos grabados, teniendo en cuenta la fecha y la importancia concedida a la imagen, revela cómo algunas supuestas visiones inciden en polémicas iconográficas contemporáneas con opiniones que se legitimarían en el carácter revelador-milagroso de las mismas, algo de lo que el autor del libro no es ajeno. ${ }^{60}$ Otro es el caso de María de la Trinidad, carmelita de Jaén, quien vio «la ymagen de la limpia Concepcion de nuestra Señora con una corona rica en la caveza y debaxo de los pies la luna aunque el manto tirava a blanco» ${ }^{61}$ -aludiendo, con este color, al manto del Carmelo descalzo. Y con ambas citas recordamos a Pacheco, definiendo entonces la iconografía de los clavos de los pies de Cristo - cuatro, contra lo defendido por este autor- o de la Inmaculada -de túnica blanca y manto azul, pisando la luna. ${ }^{62}$ Hay que añadir las visiones de Juan con el Niño en brazos y gestos de ternura, recordando santos conocidos de iconografía semejante. Y la insistencia legitimadora en el hábito del Carmen: todo redunda en la consciencia de la importancia de la retórica visual, por estos sutiles definidores de la imagen.

Como Alonso, Quiroga trata de ir más allá de lo formal, e intenta fundamentar teológicamente las apariciones con el referente místico de la filosofía de Pseudo Dionisio Areopagita, con la que se asocia a la de Juan de la Cruz; dice:

Tratando San Dionisio de las figuras y semejanças que proceden de la saviduria divina, significativas de misterios escondidos, dize estas palabras. No estimamos estas formaciones y figuras aparentes, porque ayan sido formadas para solo la vista dellas: sino porque nos son propuestas para significación de secreta e invisible saviduria [...] Asentado [...] que estas ymagines que se representan en la carne de nuestro venerable Padre es obra de la saviduria

59. José De Jesús María (Quiroga): Historia de la vida y virtudes del venerable P. F. Juan de la Cruz, 1628, p. 987-988.

60. Nos referimos a la polémica sobre la existencia de tres o cuatro clavos para la crucifixión de Cristo. $\mathrm{O}$ a la naciente configuración de la imagen de la Inmaculada Concepción de la que los Carmelitas son defensores desde el principio.

61. José de Jesús María (Quiroga): Historia de la vida y virtudes del venerable P. F. Juan de la Cruz, 1628 , p. 989. 1649.

62. Francisco Pacheco: Arte de la pintura, su antigüedad y grandezas, Sevilla: Simon Faxardo, 
divina [...] avemos de tener por cierto conforme a esta doctrina deste sumo Teologo, que no son figuras ociosas sino que cada una dellas tiene sobre aquella apariencia material que se ve, significación espiritual de misterio secreto». ${ }^{63}$

Recordemos el texto de Alonso y fijémonos en estas últimas reflexiones; Quiroga, Alonso y el jesuita al que este cita, repiten el mismo argumento y casi con las mismas palabras. La hermenéutica que defienden es la misma, parte incluso de una misma definición que, además de legitimar las apariciones en las reliquias, fundamenta la imagen del Cristo oculto. Tal hermenéutica, como después veremos, deriva de los propios textos sanjuanistas. La importancia del argumento -y sus raíces-, hecho por quienes elaboraron la construcción de tal imagen, es evidente.

Entre las publicaciones de estas biografías tiene lugar la construcción de la capilla funeraria del santo, en Segovia, de la que tenemos descripción de 1627; se destruyó en 1647 a instancias eclesiásticas ya que aún no se le había concedido a Juan el rango de santo y se prohibía su culto. ${ }^{64}$ En el sepulcroretablo de esta había tres cuadros en torno a la Virgen del Carmen: S. Juan como Doctor de la Iglesia, escribiendo; otro al fallecer y otro con «las apariciones en su carne» (Ms 012738-011, p. 521, B.N.). ${ }^{65}$ Pero no se especifica más; formaron parte del intento de divulgar una iconografía milagrosa para insistir en el éxito de su proceso de beatificación/canonización. Y se vuelve a ellas cuando, tras la beatificación, en 1675, se decora otra vez la capilla. Collar de Cáceres ${ }^{66}$ recoge el dato de Fray Manuel de Santa María (de un manuscrito de 1780) quien señala cómo, entre otras, se pusieron «en la capilla, tres pinturas de "apariciones"», sin proporcionar más detalles.

La séptima biografía es la de Francisco de Santa María (Pulgar de Sandoval), entonces historiador de la orden, en su Reforma de los Descalzos, Madrid, 1655, en su segundo tomo (había dedicado el primero, en especial, a Santa Teresa). Habla de las apariciones en la carne, milagro «raro» que cuenta siguiendo, según explica, a Jerónimo de San José. Dice:

Aparecese algunas vezes [...] un Fraile Carmelita Descalço, solo, otras

63. José de Jesús María (Quiroga): Historia de la vida y virtudes del venerable P. F. Juan de la Cruz, 1628, p. 997-998.

64. «Los Decretos de Urbano VIII de 1625 y 1634 [...] prohibían manifestaciones cultuales sin el permiso de la Iglesia antes que se hubiese producido la beatificación». (EMILIA MONTANER: «La configuración de una iconografía, 1991, p. 156).

65. Se corresponde a un texto manuscrito que describe la capilla preparada para la recepción de las «Letras remissoriales en orden a la beatificación del venerable y santo de Fray Juan de la Cruz Primer Religioso y Reformador de los Carmelitas Descalços», 1627, en Ms 012738-011, fol. 521, B.N. Jerónimo de S. José describe la capilla de Segovia, incluido su sepulcro con los tres cuadros, estos de forma escueta (JERóNimo de SAn José: Historia del Venerable Padre Fray Juan de la Cruz, 1641, pp. 824- 828).

66. Fernando Collar de CÁCEREs: «En torno a la iconografía de san Juan de la Cruz», 1983, p. 22. 
adorando un Christo; otras reverenciando a la Virgen Santissima, que traia su santo Niño en los braços; otras descubiertas todas estas figuras; otras no mas que la mitad, i la otra cubierta de nubes. De suerte que, la multitud de las apariciones, la continuación dellas, la variedad [...] el modo, unas vezes con claridad, otras con confusion, el numero grande de testigos [...] hacen el caso indubitable.

Y añade, refiriéndose a él mismo: «aunque nunca merecimos ver alguna».67 Efectivamente, Pulgar ni vio ni comprendió el significado metafórico de la nube, solo aplicable a Cristo; él ya está lejos de los mentores de esta. Observemos el olvido del hermano.

La octava biografía es la de José de Santa Teresa, escrita con motivo de la beatificación de Juan, ${ }^{68}$ en 1675. Aquí solo se dice: «Reliquias con las apariciones maravillosas que en la carne de el Santo se han visto y comprobado. Mas porque esto tiene muchas circunstancias [...] remito al Lector a los Escritores de su vida». ${ }^{69}$

En un manuscrito (B.N. Ms. 012738-027, pp. 1363-1374) que Collar ${ }^{70}$ sitúa como posterior a 1675, un mentor detalla la iconografía a desarrollar en estampas divulgadoras de la vida de Juan, quizás para arquitecturas efímeras callejeras con motivo de su beatificación. El texto, Pasos que se podran estampar de la vida de ntro. sto. Pe. Fr. Juan, anónimo, describe, en la última escena, la 24, la aparición en la carne: Juan, la Virgen con el Niño que le acaricia la cabeza, Cristo en la cruz, el Espíritu Santo como paloma y una custodia (B. N. Ms 012738-027, pp. 1372-1397). Ya no aparece Francisco ni Cristo oculto: si la insistencia en la reproducción de estas apariciones subraya el carácter milagroso, ya conocido y, por tanto, identificador de Juan, la iconografía concreta de la nube es compleja y no útil en una imagen de signo popular. De ahí su progresivo abandono. Y lo mismo sucede con la imagen del hermano: definitivamente, es la visión de Juan, no de Francisco.

La última biografía de la que hablaremos es la que se publica en 1728 , de otro Alonso de la Madre de Dios, con motivo de la canonización (27 de diciembre de 1726). ${ }^{71}$ Este Alonso, aunque homónimo, es ya un siglo posterior

67. Francisco de Santa María (Pulgar de Sandoval): Reforma de los Descalzos, 1655, p. 579.

68. Con motivo de la beatificación se publican otras biografías: la de fray Pedro de Andrés, en Aix, 1675; fray Marcos de San Francisco en Lovaina, 1675; fray Gaspar de la Anunciación en Bruselas, 1678; y la del Obispo don Fernando Correa de la Cerda, en Lisboa, 1680. (Fernando Collar de CÁCEREs: «En torno a la iconografía de san Juan de la Cruz», 1983, pp. 19-20).

69. José de Santa Teresa: Resunta de la vida de N. Bienaventurado P. San Juan de la Cruz, Madrid: Bernardo de Villa- Diego, 1675, p. 131.

70. Fernando Collar de Cáceres: «En torno a la iconografía de san Juan de la Cruz», 1983, p. 33.

71. Este autor, Alonso de la Madre de Dios, homónimo del que hemos hablado (muerto en 1635), lo es también de la descripción de las celebraciones realizadas en Madrid por la canonización: ALONSO DE LA MAdRe De Dios: La Exaltacion del amador de la Cruz. Descripcion historica de los festivos cultos y obsequiosos aplausos [...] a la solemne Canonizacion de [...] San Juan de la Cruz, Madrid: Imprenta de Joseph Gonçalez, 1729. 
al que conocemos; para entonces, sobre las visiones en la carne solo dice:

En la carne inanimada de Juan se han visto repetidas veces ya Jesus, espejo sin mancilla: ya Maria, Madre de pureza: ya Elias, zelador de la divina honra: ya Teresa, desempeño de la gracia: ya el mismo Juan todo vestido de gloria: y ya el sagrado leño de la Cruz, pauta de sus finezas y compendio de sus maravillas. Que serán los triunfos de su alma, quando muestra el poder divino tantos prodigios en su cuerpo?».72

Más nos interesa cómo ensalza la enseñanza espiritual de Juan:

La fee luz indefectible, que dirige mas seguros a los que se cautivan mas ciegos, logró siempre en nuestro Juan los quilates mas realzados. Assentia a los mas arcanos mysterios tan sin zozobra, como si claramente los viera: mejor diré, que los velos con que la fe los manifiesta sagradamente ocultos, parecian mas evidencia para Juan, que si los registraran sus ojos. Contemplando siempre entre obscuros velos a la Magestad infinita, para no cegar en los golfos de la claridad inmensa [...] este entendimiento iluminado [...] tanto mas altamente entendia, y explicaba los arcanos de la Trinidad beatifica, quanto se consagraba a la fee con sumission mas ciega. Este es el modo de investigar tan elevada grandeza, sin quedar oprimido del peso de la divina Gloria; que eleva la fee ciega a el seguro conocimiento. ${ }^{73}$

Este segundo Alonso, como el promotor de la causa sanjuanista, al apoyarse en las evocaciones icónicas de la fe ciega, los velos que ocultan y manifiestan lo sagrado, deducidas de la mística de Juan y para hablar de ella, es fiel traductor de lo que habría impulsado la creación formal de Cristo oculto entre tales luminosas nubes; un siglo después, la enseñanza y la interpretación acorde con tal fórmula icónica, sigue en él, correcta, aunque la imagen como tal, ya no es frecuente.

Curiosamente, en 1748 se traducirá ese contenido en una edición veneciana de la obra literaria de Juan ${ }^{74}$ ilustrada por F. Zugni, dibujante, y F. Zucchi, grabador. En el grabado de La Noche Oscura, el alma (mujer joven y alada) sube a la cumbre del monte donde la recibe Jesús, sobre una nube y cubriéndose el rostro (Fig. 8), en una iconografía derivada del mismo concepto.

72. Alonso de la Madre de Dios. La Exaltacion del amador de la Cruz, 1729.

73. Alonso de la Madre de Dios. La Exaltacion del amador de la Cruz, 1729, p. 37.

74. Opere di san Giovanni della Croce Primo Carmelitano Scalzo [... ] con la vita del santo [... ] Tomo secondo, In Venezia MDCCXLVIII Presso angelo Geremia [... I Impresso nella Stamperia di Stefano Orlandini, p.182 Agradezco la localización de esta obra a Mercedes Ramírez Íñiguez de la Torre, bibliotecaria de la Pública de Albacete. 


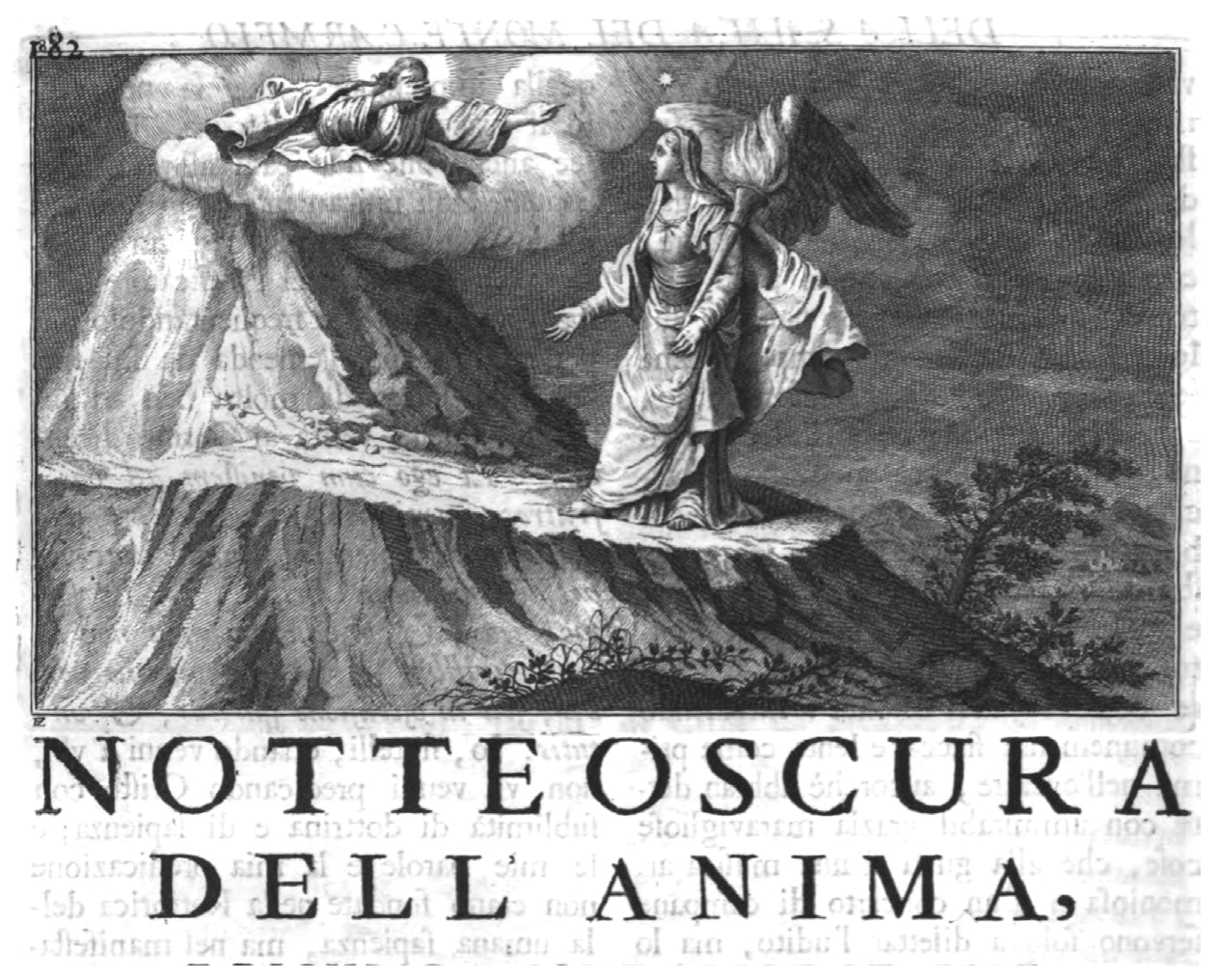

Fig. 8. F. Zugni, dibujante, y F. Zucchi, grabador, en Opere di san Giovanni della Croce Primo Carmelitano Scalzo, 1748, Venecia, p.182

En cuanto a la imagen, el propio Juan («Subida del Monte Carmelo», Libro Segundo, capítulos VIII y IX) habría dicho:

Todo lo que la imaginación puede imaginar y el Entendimiento entender en esta vida, no es ni puede ser medio próximo para la unión de Dios [...] No tiene el Entendimiento disposicion ni capacidad en la carcel del cuerpo, para recibir noticia clara de Dios [...] Por esso dixo Dios a Moysen [...] "No me verá hombre que pueda quedar vivo" [...] Y de Elias [...] se dize que en el monte se cubrió el rostro en la presencia de Dios, que significa cegar el Entendimiento [...] Porque todo lo que puede entender el Entendimiento, gustar la voluntad y fabricar la imaginacion es muy dissimil y desproporcionado [...] a Dios. Lo qual [...] dio a entender [...] el Profeta Isaias, diziendo: [...] «A que cosa aveis podido hazer semejante a Dios? O que imagen le hareis que se le parezca?». 
Esto, podría traducirse en un rechazo de la imagen para la práctica contemplativa $;{ }^{75}$ además, el entendimiento, para llegar a Dios,

Antes ha de ir no entendiendo [...] y antes cegandose y poniendose en tiniebla [...] Y de aquí es que a la Contemplacion por la qual el Entendimiento se ilustra de Dios, llaman Teologia Mistica que quiere dezir: sabiduria de Dios secreta [...] La Fé [...] sola es el proximo y proporcionado medio para que el alma se una con Dios [...] Ha de ser el Entendimiento ciego y a escuras, solo en Fé, porque debaxo desta tiniebla se junta con Dios el Entendimiento y debaxo della está Dios escondido [...] Tambien a Moysen en el monte se le aparecia en tiniebla, en que estava Dios encubierto. Y toda las vezes que Dios se comunicava $[\ldots]$ parecia en tiniebla. ${ }^{76}$

En «La noche oscura» dice:

Quanto las cosas divinas son en sí mas claras y manifiestas, tanto más son al alma obscuras y ocultas naturalmente. Assí como de la luz quanto más clara es [...] y quanto el sol se mira más de llano, más tinieblas causa en la Potencia visiva y la priva, excediendola por su flaqueza. De donde, quando esta divina luz de Contemplación embiste en el alma que aún no está ilustrada totalmente, le haze tinieblas espirituales, porque no solamente la excede, sino también la obscurece y priva el modo de su inteligencia natural [...] San Dionisio y otros Misticos Teólogos llaman a esta contemplación infusa rayo de tiniebla. ${ }^{77}$

\section{Y en «La llama» dice:}

Dios es incomprehensible y excede al Entendimiento. $\mathrm{Y}$ assi quanto mas va, mas se ha de ir alexando de si mesmo, caminando en Fe, creyendo y no viendo: y assi a Dios mas se llega no entendiendo, que entendiendo. ${ }^{78}$

75. Según Thompson (Colin P. Thompson: «El mundo metafórico de San Juan», en Actas del Congreso Internacional Sanjuanista, Ávila, Junta de Castilla y León, Volumen I, 1993, p. 87): «San Juan toma un cariz claramente erasmista [...] en su actitud hacia las imágenes, subrayando [...] que una internalización del significado de la imagen es mucho más importante que su apariencia externa; que el Cristo crucificado debe convertirse en una imagen viva dentro del alma». Y en palabras de Stoichita (Víctor I. STOICHITA: El ojo místico, 1995, p. 59): S. Juan «desecha las imágenes del ejercicio contemplativo».

76. JuAN de la CRuz: Obras del Venerable Padre Fray Juan de la Cruz, 1672, pp. 99-102.

77. JuAn de la CRuz: Obras del Venerable Padre Fray Juan de la Cruz, 1672, pp. 328. (YSABEL DE ANDíA: «San Juan de la Cruz y la "Teología Mística de San Dionisio"», en Actas del Congreso Internacional Sanjuanista, Ávila, Junta de Castilla y León, Vol. III, 1993, p. 108) compara y relaciona el «rayo de tiniebla» de Pseudo Dionisio con la divina luz de S. Juan. En el comentario de este a su verso «A oscuras y segura», Andía señala «la necesidad de esta oscuridad para que el alma pueda ser movida por Dios, lejos de todo lo que no sea Este, y llevada a la unión amorosa con Él».

78. JuAn de la CRuz: Obras del Venerable Padre Fray Juan de la Cruz, 1672, pp. 99-563. En este sentido y contraponiendo dos formas de afrontar la fe, Sánchez Lora (JosÉ LUIS SÁNCHEz Lora: El diseño de la santidad: la desfiguración de San Juan de la Cruz, Huelva: Biblioteca Montaniana Universidad de Huelva, 2004, p. 104), dice: «la mística y la escolástica son ámbitos diferentes [...] Son las dos formas o corrientes de la teología cristiana que ya vemos enfrentadas desde el siglo IV: de un lado la teología afirmativa, especula- 
En palabras de L. López-Baralt, ${ }^{79}$ "San Juan castiga nuestro entendimiento y prefiere dejar a Dios sugerido antes que explicitado».

En las cartas que escribe a sus fieles, Juan insiste en que Dios ayuda al alma cuando le oscurece las potencias para no pecar; se debe perseguir «solo vivir en fee escura y berdadera» (Mss-012738- 022, B. N., p. 1091). Y en sus poesías, las que, como él mismo explica en la «Subida del Monte Carmelo» suponen los distintos pasos del alma en su ascesis por las tres vías de la teología mística (purgativa, iluminativa y unitiva), insiste en ese concepto de la oscuridad, como paso previo a la divina comunicación de la trascendencia. Crisógono de Jesús Sacramentado ${ }^{80}$ apunta: «Las sombras, las noches oscuras son el medio; el fin es la luz». Y Ricard ${ }^{81}$ señala:

Por fe creemos en el misterio de la Trinidad, por fe aceptamos el otro misterio de la presencia de Cristo en la Eucaristía. Fe oscura y luminosa: Lux in tenebris lucet, "ya lo veo, aunque de noche" [...] La revelación es luz, pero nos propone misterios que rebasan la naturaleza y la razón, y por ello la fe es oscura y luminosa al mismo tiempo».

Así se deja ver en el poema «Cantar de la alma que se huelga de conocer a Dios por Fé»:

Qué bien sé yo la fuente que mana y corre/ aunque es de noche/ Aquella eterna fuente que está escondida/ Que bien sé yo do tiene su manida [...] Su claridad nunca es escurecida/ y sé que toda luz della es venida/ aunque es de noche. ${ }^{82}$

O en el denominado «Coplas hechas por nuestro Venerable Padre Fray Juan de la Cruz en un extasi de alta contemplacion»:

Entreme donde no supe/ y quedeme no sabiendo/ toda ciencia trascendiendo/ Yo no supe donde estaba/ pero, cuando alli me vi [...] grandes cosas entendi [...] El que allí llega de vero/ de si mismo desfallece/ cuanto sabía primero / mucho bajo le parece [...] Cuanto más alto se sube/ tanto menos se entendia/ que es

tiva y racionalista, que alcanza su mejor definición con Santo Tomás; de otro la teología apofática, negativa, defendida ya en el siglo IV por Gregorio de Nisa [...] y en el siglo V por S. Dionisio y S. Agustín, de corte neoplatónico, y que culmina en la modernidad con San Juan de la Cruz y la noche oscura de los sentidos, el Dios escondido que escapa a la razón y a la imaginación por inefable, al que solo se puede llegar por la unión de amor, fe y esperanza, que reemplazan a la voluntad, el entendimiento y la memoria».

79. Luce López-BArAL: «"El Cántico Espiritual” o el jubileo de la unión transformante», en Actas del Congreso Internacional Sanjuanista, Ávila, Junta de Castilla y León, Vol. I, 1993, pp. 194.

80. Crisógono de Jesús SaCramentado: «Relaciones de la mística con la filosofía y la estética en la doctrina de San Juan de la Cruz», Escorial, Revista de Cultura y Letras, 25, 1942, pp. 362.

81. Robert Ricard: Estudios de literatura religiosa española. Madrid: Gredos, 1964, p. 179.

82. JUAN DE LA CRUz: Obras del Venerable Padre Fray Juan de la Cruz, 1672, s.p. 
la tenebrosa nube/ que a la noche esclarecia [...] Y si lo quereis oir,/ consiste esta suma ciencia/ en un subido sentir / de la divinal esencia/ es obra de su clemencia/ hacer quedar no entendiendo,/ toda ciencia trascendiendo. ${ }^{83}$

O, finalmente, en «Subida del Monte Carmelo», las:

Canciones en que canta el Alma la dichosa ventura que tuvo en passar por la Obscura Noche de la Fé en desnudez y purgacion suya a la union de el Amado»: «En una noche obscura,/ Con ansias en amores inflamada [...] Salí sin ser notada [...] A escuras y segura,/ por la secreta escala disfrazada, [...] O noche que guiaste!/ O noche amable más que el alborada!/ O noche que juntaste/ Amado con Amada, / Amada en el Amado transformada! ${ }^{84}$

En consecuencia, vemos a Juan creador de metáforas como la de la «oscuridad», la «noche», la «tiniebla»y el «rayo de tiniebla», que podemos interpretar por nube luminosa. ${ }^{85}$ Ahí traduce su relación con la mística de Pseudo Dionisio Areopagita ya que, según este, Dios es el mismo foco luminoso, al que se llega desde la oscuridad. El concepto de la oscuridad se une al de la nube, y la nube revela lo divino, detrás de ella está la luz. En Éxodo 13, 21, es la nube luminosa la que guía a los israelitas por el desierto:

En la Biblia, las nubes son los instrumentos de la Revelación. Muestran y ocultan a la vez, asumiendo así su estatus de límite en relación con lo visible [...] Para Juan de la Cruz, la nube es lo concreto de la visión, lo visible palpable en el límite de lo sacro [...] inútil barrera entre lo místico y lo divino. ${ }^{86}$

A sus metáforas, muy visuales, Juan otorga un sentido «a lo divino», como explica en su reflexión para «Canciones entre el alma y Christo, su Esposo»; dice:

Sería ignorancia pensar que los dichos de amor de Dios y inteligencia Mistica [...] con alguna manera de palabras se puedan bien explicar [...] porque quien podra escrivir lo que a las almas amorosas donde él [el Espíritu del Señor] mora haze entender? Y quien podra manifestar con palabras lo que las haze sentir? [...] Que esta es la causa porque con figuras o comparaciones o semejanças grandes, rebossan algo de lo que sienten, y de la abundancia del espiritu vierten secretos misteriosos que con razones lo declaran. Las quales

83. JuAn de la Cruz: Obras del Venerable Padre Fray Juan de la Cruz, 1672, s.p

84. JUAN DE LA CRUz: Obras del Venerable Padre Fray Juan de la Cruz, 1672, pp. 37-38.

85 «Los teólogos tratan de aprisionar en fórmulas escolásticas lo que los místicos experimentan y describen por imágenes, comparaciones y semejanzas» (MELQUiAdES A. MARTíN: «En torno a los procesos de clarificación en la mística española», en Actas del Congreso Internacional Sanjuanista, Ávila, Junta de Castilla y León, Vol. II, 1993, p. 480).

86. Víctor I. Stoichita: El ojo místico, 1995, p. 81. 
semejanças, no leidas con la sencillez del espiritu de amor y inteligencia que ellas llevan, antes parecen dislates, que dichos puestos en razon, según es de ver en los Divinos Cantares de Salomon, y en otros libros de la Escritura divina, donde no queriendo el Espiritu Santo dar a entender la abundancia de su sentido, por terminos vulgares y usados, habla misterios en estrañas figuras y semejanças. ${ }^{87}$

De esta manera, el mismo Juan pone las bases para la construcción de la imagen del Cristo envuelto en la nube, pero una nube brillante, luminosa, reveladora de la divinidad: ${ }^{88}$ es el camino de la "fe oscura». Así mismo, el rechazo del entendimiento y la valoración de la fe tendría su reflejo en los ojos cerrados -o el olvido de los sentidos- con que se representa a Juan en las escenas en las que intuiría, dentro de sí, a Cristo oculto, plasmación de la imposible imagen de lo divino. El mismo Juan, en «Subida del Monte Carmelo» (libro III, capítulos 34 y 36), había dicho:

La persona devota en lo invisible principalmente pone su devocion y pocas imágenes ha menester y de pocas usa [...] Ni en essas de que usa tiene assido el coraçon; y assi si se las quitan, se pena mas poco: porque la viva Imagen busca dentro de si, que es Cristo crucificado [... Tenga por cierto el alma, que cuanto mas assida [...] estuviere a la Imagen [...] tanto menos subirá a Dios su devocion y oración. ${ }^{89}$

En el mismo manuscrito en que se recopilan los testimonios sobre Juan y la reliquia, muchos de la mano del primer Alonso, hay un escrito, probablemente de este autor, que es un prólogo a la obra literaria de Juan. Incide en su valoración de la imagen:

Es tan alta la perfeccion a que encamina las almas, y tan extraordinaria la negacion, desnudez y pobreza, por donde a este fin tan alto y soberano, de la union perfecta con su Dios, las quiere guiar, que muchos se acobardan [...] y desconfian de poderle alcanzar [...] pareciendoles a muchos que no saben [...] el tener oracion sino es por imagines y semejanzas, que estan para siempre pribados de poder llegar a una perfeccion tan alta que pide una total desnudez de esas mesmas imagines, figuras y semejanzas.

87. JuAn De la CRUz: Obras del Venerable Padre Fray Juan de la Cruz, 1672, p. 387.

88. Orozco (Emilio Orozco Díaz: «La palabra, espíritu y materia en la poesía de San Juan de la Cruz», en Escorial, Revista de Cultura y Letras, 25, 1942, pp. 316-329) constata las alusiones que Juan pretende con las imágenes que describe: «mundo de imágenes que tan fuertemente nos hiere con sus evocaciones o sugerencias en el campo de lo sensorial» y que usa «transcendiendo su sentido directo» para «gustar y ver su significación mística [...] Su estilo figurado, pues, surge como una necesidad no propiamente literaria, sino espiritual o mística [...] Asociación del símbolo a la palabra o, mejor dicho, el empleo y la valoración de los elementos de la Naturaleza como símbolos [...] Pensemos en la "noche" símbolo fundamental de su doctrina».

89. JuAn de la CRuz: Obras del Venerable Padre Fray Juan de la Cruz, 1672, pp. 262-268. 
De entre estos que no saben, los hay

altivos y presuntuosos, aunque muy agudos y doctos [...] [pero] como no son hombres de oracion, no saben ni alcanzan mas que un poco de discurso seco [...] conque algunas veces piensan y discurren en la passion y vida de Christo [...] quedandose seca la voluntad y el alma porque a la verdad no tienen espiritu ni oracion [...] carecen de verdadera humildad (Mss-012738028, B.N. pp. 1471- 1473).

Pensamos que desde aquí se esgrime una defensa de la mística sanjuanista, frente a la «composición de lugar», llena de imágenes, jesuita. S. Juan, propone, con los ojos cerrados (es decir: sin necesidad de imágenes), conducir al alma hacia la intuición de lo divino, Cristo oculto en la nube.

Tal imagen, compleja elaboración intelectual, fue obra de Alonso de la Madre de Dios (Martínez, de Astorga), de José de Jesús María (Quiroga) y de José de Jesús María (Martínez Medina), General de la Orden, quienes la crearon para plasmar y así explicar y defender, la enseñanza mística de Juan de la Cruz, al que admiran, frente a calzados, a jesuitas y a los que le acusan de «alumbrado $»^{90}$ (entorpeciendo la causa de canonización del santo). Esa enseñanza mística era el concepto sanjuanista de la «fe oscura» y de la imposible imagen de lo divino: Cristo envuelto en la nube brillante, intuido en el corazón de un Juan con ojos cerrados. El brillo muestra lo sagrado y le vincula con la doctrina de Pseudo Dionisio Areopagita. Los mencionados carmelitas contaron con dos figuras de las que es necesario destacar su relevancia ya que fueron quienes dieron forma visible a tales contenidos; de ambos hay que señalar su vinculación directa a los anteriores, como autores intelectuales. Los dos confiesan ser testigos de las visiones. Son el pintor Pedro de Soria, supervisado por el obispo Vigil, cuyas primeras imágenes hoy son desconocidas, y Diego de San José, secretario de José de Jesús María, General de la Orden, a quien atribuimos la autoría, al menos intelectual, del grabado que aparece anónimo en el Manuscrito 012738-001.

El simbolismo buscado por S. Juan es entendido por la persona que escribe este poema, que aparece anónimo -la autora es Cecilia Sobrino de Morillas, carmelita- ${ }^{91}$ en el conjunto manuscrito de informes sobre Juan y la reliquia,

90. Sobre las acusaciones de que fue objeto la mística de S. Juan y los argumentos de su defensa, ver la «Introducción» de Fortunato Antolín (Fortunato Antolín: José de Jesús María (Quiroga), 1991, pp. 125-146) a la «Apología Mística» (pp. 147-316) de José de Jesús María (Quiroga); Eulogio DE LA VirGEN DEL CARMEN: «Primeras ediciones del Cántico Espiritual, 1967.

91. Cecilia Sobrino de Morillas, sor Cecilia del Nacimiento (Valladolid 1570-1646), carmelita descalza y poeta. Su título: «Canciones de la Unión y Transformación del alma en Dios, por la tiniebla divina de pura contemplación». Sobre esta autora ver: José Adriano De Freitas CARvalho: «Las cartas de la monja Cecilia del Nacimiento», en Revista SIECE, Perspectivas actuales de la investigación sobre escritura y comunicación escolar, Universidad de Alcalá, 2009-2010; LuIS J. F. FrontelA: «Cecilia del Nacimiento, Monja Carmelita Descalza y escritora», en Revista de Espiritualidad, 72, 2013, pp. 159-172. 
fechable en las primeras décadas del siglo XVII, hasta los años 30. Se titula «A nuestro Venerable Padre Fray Juan de la Cruz» y se construye con su mística y muchos de sus versos:

Aquella noche obscura/ Es una luz divina fuerte hermosa/ Inaccesible y pura/ Yntima y deleytosa/ Un ver a Dios sin vista de otra cosa/ La qual a gozar llega/ El alma que de amor está inflamada/ Y viene a quedar ciega/ Quedando sin ver nada/ La ciencia transcendida y alcanzada/ Y quando la conquista/ Del reyno de si misma es acabada/ Si sale sin ser vista/ De nadie ni notada/ A buscar a su Dios del inflamada/ Y en aquesta salida/ Que sale de sí el alma dando un buelo/ En busca de su vida/Sube al empyreo cielo/ Y a su secreto centro quita el velo [...] El amor la encamina/ metida entre tiniebla muy obscura/ y sin otra doctrina/ camina mas segura/ A donde Dios le muestra su hermosura/ y yendo este camino/ sin luz de entendimiento ni memoria/ le muestra el rey divino/ su virtud y su gloria/ como se puede en vida transitoria [...] Negandose a si mismo/ Por no negar aquello que nunca niega/ Entre en el dulce abismo/ De aquella noche ciega/ Do halla viva luz el que se entrega/ Y en lo más escondido/ De aquella escuridad resplandeciente/ Saliendo esclarecido/ El sol que está presente/ Hace la noche día refulgente [...] La luz en la tiniebla/ La tiniebla en la luz sin apartarse/ La claridad en niebla/ La niebla en luz mostrarse/ En este abismo va sin estorbarse / Porque puso tiniebla / Con su divina luz su ser y esencia/ Para que visto en niebla/ Con secreta asistencia/ Aca pueda gozarse su presencia (Mss-012738-023 B. N., pp. 1197-1200).

Si ya Boecio (ca. 480-525) figuraba a la filosofía con una altura cuya cabeza podía no solo tocar sino «penetrar en los mismos cielos, perdiéndose de vista», ${ }^{92}$ con una cronología aproximada a Juan, C. Ripa ${ }^{93}$ (Iconología, Roma, 1593-1603) desarrolla su concepto sobre la belleza, muy platónico y cercano a Pseudo Dionisio Areopagita. Recordemos que, para Platón, la absoluta belleza se identifica con la absoluta verdad y bondad, en definitiva, con Dios. Así, de una forma paralela al concepto de la divinidad sanjuanista, la iconografía de la belleza es descrita por Ripa de esta forma:

Se pinta la Belleza con la cabeza oculta entre las nubes por no haber cosa mas difícil de describir para nuestras lenguas mortales siendo, además, dif ícilmente

92. Boecio, Consolación de la Filosofía. Citado por Gombrich (Gombrich, ERnst H.: Imágenes simbólicas, Madrid: Alianza, 1983, p. 223). Debo y agradezco esta observación al profesor R. García Mahíques.

93. Cesare Ripa: Iconología, [1593]. Madrid: Akal, 1987. La primera edición fue en Roma, en 1593 (Per gli Heredi di Gio. Gigliotti), pero sin imágenes. La primera ilustrada es la de Roma, por Lepido Faeii, en 1603. 
cognoscible para el humano intelecto. Pues esta, de entre todas las cosas creadas y metafóricamente hablando, no es sino un esplendor derivado de la luz que desprende la divina faz, según la definen los Platónicos. De modo que la belleza primera viene a ser una con Dios; y luego difundiéndose de algún modo en forma de Idea por benignidad del Señor hacia sus criaturas, es preciso que estas, de alguna forma, la reflejen. ${ }^{94}$

El carácter intelectual y complejo del concepto plasmado en el Cristo oculto, hizo que tal iconografía sanjuanista no proliferara, especialmente a niveles divulgativos. Nos lo demuestra su desaparición de las imágenes que se ofrecen al pueblo en general, en calles o iglesias, en decoraciones ef ímeras, motivadas por su canonización; ejemplo de ello es la de Madrid, donde las apariciones sí son mencionadas en los sermones, aunque de forma genérica, llegando a incluir a Elías y a santa Teresa; y nunca se menciona al Cristo oculto. ${ }^{95}$

\section{BIBLIOGRAFÍA}

Alonso de la Madre de Dios (Martínez): Vida, virtudes y milagros del Santo Padre Fray Juan de la Cruz Maestro y Padre de la Reforma de la Orden de los Descalzos de Nuestra Señora del Monte Carmelo, Edición de Fortunato Antolín, Madrid: Ed. Espiritualidad, 1989.

Alonso de la Madre de Dios: Epitome Historico Panegyrico, Vida, Virtudes y Milagros del Extatico Padre y Mistico Doctor, S. Juan de la Cruz, Barcelona: Imprenta de los Padres Carmelitas Descalzos, 1728.

Alonso de la MAdRe De Dios: La Exaltacion del amador de la Cruz, Madrid: Imprenta de Joseph Gonçalez, 1729.

Andía, YSABel DE: «San Juan de la Cruz y la "Teología Mística de San Dionisio"», en Actas del Congreso Internacional Sanjuanista, Ávila, Junta de Castilla y León, Vol. III, 1993, pp. 97-125.

Antolín, Fortunato: José de Jesús María (Quiroga), Alonso de la Madre de Dios, Jerónimo de S. José (Ezquerra), Primeras biografías y apologías de S. Juan de la Cruz, Salamanca: Junta de Castilla y León, Consejería de Cultura y Turismo, 1991.

Bouzá Álvarez, José luis, Domínguez Ortiz, Antonio y Caro Baroja, Julio: Religiosidad contrarreformista y cultura simbólica del Barroco, Madrid: CSIC, 1990.

Carrete Parrondo, Juan, Checa Cremades, Fernando y Bozal, Valeriano: Summa Artis. Vol. XXXI, El grabado en España (Siglos XV-XVIII), Madrid: Espasa Calpe, 1987.

Collar de Cáceres, Fernando: «En torno a la iconografía de san Juan de la Cruz. A propósito de su capilla-mausoleo», en Boletín del Museo e Instituto Camón Aznar, XIII, 1983, pp. 19-40.

CRisógono de Jesús SACRAmentado: «Relaciones de la mística con la filosofía y la estética en la doctrina de San Juan de la Cruz», en Escorial, Revista de Cultura y Letras, 25, 1942, pp. 353-366.

94. CESARE RIPA: Iconologia, 1987, p. 131.

95. Alonso de la Madre de Dios. La Exaltacion del amador de la Cruz, 1729. 
-: Vida de S. Juan de la Cruz, Madrid: B.A.C., 1946.

Efrén de la Madre de Dios y Stegging, O.: Tiempo y vida de S. Juan de la Cruz, Madrid: B.A.C., 1992.

Egido, Teófanes: «Claves históricas para la comprensión de san Juan de la Cruz», en SAlvador Ros et al.: Introducción a la lectura de san Juan de la Cruz, Salamanca, Junta de Castilla y León, Consejería de Cultura y Turismo, 1991.

-: «Hagiografía y estereotipos de santidad contrarreformista (La manipulación de san Juan de la Cruz)», en Cuadernos de Historia Moderna, 25, 2000, pp. 61-85.

Eulogio de la Virgen del Carmen: «Primeras ediciones del Cántico Espiritual», Ephemerides Carmeliticae, 18, 1, 1967, pp. 3-48.

Francisco de Santa María (Pulgar de Sandoval): Reforma de los Descalzos de Nuestra Señora del Carmen, Madrid: Diego Díaz de la Carrera, 1655.

Freitas Carvalho, José Adriano De: «Las cartas de la monja Cecilia del Nacimiento», en Revista SIECE, Perspectivas actuales de la investigación sobre escritura y comunicación escolar, Universidad de Alcalá, 2009-2010.

Frontela, Luis J. F.: «Cecilia del Nacimiento, Monja Carmelita Descalza y escritora», Revista de Espiritualidad, 72, 2013, pp. 159-172.

García Vega, BlanCa: El grabado del libro español. Siglos XV-XVI-XVII, Valladolid: Diputación Provincial, I y II, 1984.

Garrido, Pablo M.: S. Juan de la Cruz y Francisco de Yepes. En torno a la biografía de los dos hermanos, Salamanca: Sígueme, 1989.

Gombrich, Ernst H.: Imágenes simbólicas, Madrid: Alianza, 1983.

Jerónimo de SAn José: «Dibuxo del venerable Varón Fray Juan de la Cruz», en JUAN DE LA Cruz, Obras del Venerable Padre Fray Juan de la Cruz, Madrid, Bernardo de Villa Diego, 1672, pp. 1-38.

-: Historia del Venerable Padre Fray Juan de la Cruz, Madrid: Diego Díaz de la Carrera, 1641.

José de Jesús María (Quiroga): Historia de la vida y virtudes del venerable P. F. Juan de la Cruz, Bruselas: Juan de Meerbeeck, 1628.

José de Jesús María (Martínez Medina) y Vigil de Quiñones: Relación de un insigne milagro que Nuestro Señor obra continuamente en una parte de carne del Venerable Padre Fray Juan de la Cruz, Madrid: Viuda de Alonso Martín, 1615.

José de Santa Teresa: Resunta de la vida de N. Bienaventurado P. San Juan de la Cruz, Madrid: Bernardo de Villa-Diego, 1675.

JUAN DE LA CRUZ: Obras Espirituales que encaminan una alma a la perfecta unión con Dios. Barcelona: Sebastián Cormellas, 1619.

-: Obras del Venerable Padre Fray Juan de la Cruz, Madrid: Bernardo de Villa-Diego, 1672.

-: Opere di san Giovanni della Croce Primo Carmelitano Scalzo [... ] con la vita del santo, Venezia: Stefano Orlandini, 1748.

López-BARAlt, LuCE: «"El Cántico Espiritual” o el jubileo de la unión transformante», en Actas del Congreso Internacional Sanjuanista, Ávila, Junta de Castilla y León, Vol. I, 1993, pp. 163-204.

Maravall, José Antonio: La cultura del Barroco, Madrid: Ariel, 1980.

Martín Melquiades, A.: «En torno a los procesos de clarificación en la mística española», en Actas del Congreso Internacional Sanjuanista, Ávila, Junta de Castilla y León, Vol. II, 1993, pp. 473-482.

Martínez González, Emilio J.: Tras las huellas de Juan de la Cruz. Nueva biografía, Madrid: Ed. Espiritualidad, 2006.

Montaner, Emilia: «La configuración de una iconografía: las primeras imágenes de San Juan de la Cruz», en Mélanges de la Casa de Velázquez, 27, 2, 1991, pp. 155-167.

Moreno Cuadro, Fernando: «Origen andaluz de la Vera Effigies de san Juan de la Cruz y su repercusión en Flandes y México», en Laboratorio de Arte, 25, 2013, pp. 347-370. 
—: «Iconografía de los testigos de los procesos teresianos. A propósito de Adrian Collaert y la escenografía de la Capilla Cornaro», en Archivo Español de Arte, LXXXVII, 345, 2014, pp. 29-44.

Orozco Díaz, Emilio: «La palabra, espíritu y materia en la poesía de San Juan de la Cruz», en Escorial, Revista de Cultura y Letras, 25, 1942, pp. 315-335.

Pacheco, Fr ancisco: Arte de la pintura, su antigüedad y grandezas, Sevilla: Simon Faxardo, 1649.

Ripa, CeSARE: Iconologia, [1593]. Madrid: Akal, 1987.

Ricard, Robert: Estudios de literatura religiosa española. Madrid, Gredos, 1964.

Rodríguez-San Pedro Bezares, Luis E.: «Notas y comentarios. Tras las huellas de san Juan de la Cruz. Los contextos de una biografía», en Revista de Espiritualidad, 67, 2008, pp. 481-500.

Sánchez Cantón, F. J.: «¿Cabe hablar de S. Juan de la Cruz y las artes?», en Escorial, Revista de Cultura y Letras, 25,1942, pp. 301-314.

SÁnChez Lora, José Luis: El diseño de la santidad: la desfiguración de San Juan de la Cruz, Huelva: Biblioteca Montaniana Universidad de Huelva, 2004.

Stoichita, Víctor I.: El ojo místico. Pintura y visión religiosa en el Siglo de Oro español, Madrid: Alianza, 1995.

Summa de la vida y milagros del Venerable Padre Fray Juan de la Cruz primer Descazo de la reforma de nuestra Señora del Carmen, sacada de las informaciones que se an hecho para su Canonizacion. En Amberes. En casa de Pedro y Juan Belleros. MDCXXV.

Thompson, Colin P.: «El mundo metafórico de San Juan», en Actas del Congreso Internacional Sanjuanista, Ávila, Junta de Castilla y León, Volumen I, 1993, pp. 75-93.

Valero Collantes, Ana Cristina: «Una reliquia de San Juan de la Cruz custodiada en el Convento carmelitano de San José (Medina del Campo). Milagro transformado en arte», en De Arte, 8, 2009, pp. 47-54.

Velasco, José DE: Vida, virtudes y muerte del Venerable Francisco de Yepes, Valladolid: Juan Godinez de Milles, 1616.

-: Vida, virtudes y muerte del Venerable Francisco de Yepes. Edición de Ana Díaz Medina, Valladolid: Junta de Castilla y León, 1992. 